Article

\title{
Experimental and Modeling Studies on the Conversion of Inulin to 5-Hydroxymethylfurfural Using Metal Salts in Water
}

\author{
Boy Arief Fachri ${ }^{1,2, \dagger}$, Carolus Borromeus Rasrendra ${ }^{3, \dagger}$ and Hero Jan Heeres ${ }^{1, *}$
}

1 Chemical Engineering Department, University of Groningen, Nijenborg 4, 9747 AG Groningen, The Netherlands; E-Mail: fachri.b.arief@gmail.com

2 Faculty of Engineering, University of Jember, Jember 58121, Indonesia

3 Chemical Engineering Department, Bandung Institute of Technology, Bandung 40132, Indonesia; E-Mail: cbr@che.itb.ac.id

$\dagger$ These authors contributed equally to this work.

* Author to whom correspondence should be addressed; E-Mail: h.j.heeres@rug.nl; Tel.: +31-50-363-4174; Fax: +31-50-363-4479.

Academic Editor: Rafael Luque

Received: 24 October 2015 / Accepted: 14 December 2015 / Published: 21 December 2015

\begin{abstract}
Inulin, a plant polysaccharide consisting of mainly D-fructose units, is considered an interesting feed for 5-hydroxymethylfurfural (HMF), a top 12 bio-based chemical. We here report an exploratory experimental study on the use of a wide range of homogeneous metal salts as catalysts for the conversion of inulin to HMF in water. Best results were obtained using $\mathrm{CuCl}_{2}$. Activity-pH relations indicate that the catalyst activity of $\mathrm{CuCl}_{2}$ is likely related to Lewis acidity and not to Brönsted acidity. The effects of process conditions on $\mathrm{HMF}$ yield for $\mathrm{CuCl}_{2}$ were systematically investigated and quantified using a central composite design $\left(160-180{ }^{\circ} \mathrm{C}\right.$, an inulin loading between 0.05 and $0.15 \mathrm{~g} / \mathrm{mL}, \mathrm{CuCl}_{2}$ concentration in range of $0.005-0.015 \mathrm{M}$, and a reaction time between 10 and $120 \mathrm{~min}$ ). The highest experimental HMF yield in the process window was $30.3 \mathrm{wt} . \%\left(39 \mathrm{~mol} \%, 180{ }^{\circ} \mathrm{C}\right.$, $0.05 \mathrm{~g} / \mathrm{mL}$ inulin, $0.005 \mathrm{M} \mathrm{CuCl}_{2}$ and a reaction time of $10 \mathrm{~min}$ ). The HMF yields were modelled using non-linear, multi variable regression and good agreement between experimental data and model were obtained.
\end{abstract}

Keywords: inulin; metal salts; $\mathrm{HMF}$; levulinic acid; $\mathrm{CuCl}_{2}$ 


\section{Introduction}

The depletion of fossil resources (oil, coal, and natural gas) and environmental concerns regarding the emissions of $\mathrm{CO}_{2}$ have boosted research activities on the development of fuels and chemicals from renewable resources [1-8]. Biomass is an interesting renewable feed as it is abundantly available on a sustainable basis [9-18]. Research on biobased chemicals from biomass and particularly the carbohydrate fractions has intensified in the last decades. Examples of target molecules with high application potential are levulinic acid (LA), lactic acid, and furanics like 5-hydroxymethylfurfural (HMF). HMF has been categorised as a top (12) biobased chemical by the US Department of Energy (DOE) $[2,9]$ and has a high and broad application and derivatisation potential. Examples are the use of HMF as a starting material for renewable monomers for the polymer industry, or for solvents and biofuel additives [13,19-21]. HMF synthesis involves the use of the C6 sugars in the biomass, like D-glucose and D-fructose. A wide range of typically Brönsted acid catalysts (homogeneous and heterogeneous) and solvents (mono- and biphasic) have been proposed; for more details see recent reviews by Wang et al. [3], van Putten et al. [5]. In general, HMF yields with D-fructose as a feed are considerably better than for D-glucose [5].

Recently, the use of (cheap) metal salts as catalysts for the conversion of C6 sugars to HMF has been proposed in water and organic solvents (including ionic liquids) [5]. Our interest in this field is particularly on the use of water as a reaction solvent as (i) it is environmentally benign and, (ii) C6-sugars are reasonably soluble in water. An overview of relevant examples of conversions of C6 sugars (D-glucose, D-fructose) in water using soluble metal salts, in some cases in combination with a Brönsted acid (like $\mathrm{HCl}$ ), is given in Table 1. The highest $\mathrm{HMF}$ yields for D-fructose were $80 \mathrm{~mol} \% \mathrm{using} \mathrm{InCl}_{3}$ as the soluble metal salt. Typical byproducts are organic acids like levulinic acid (LA), formic acid, lactic acid, and insoluble byproducts known as humins.

An interesting recent development is the conversion of D-glucose to HMF using a tandem isomerisation-dehydration reaction with metal salts as the catalysts. Here, it is speculated that a Lewis acid metal centre catalyses the isomerisation of D-glucose to D-fructose, followed by the conversion of D-fructose to HMF. Whereas the initial focus for the tandem isomerisation-dehydration reaction was on water only (max. 40\% HMF yield), recent advances show that biphasic systems allow for higher HMF yields (up to $62 \mathrm{~mol} \%$, see Table 1 for details). 
Table 1. Overview of reactions of D-fructose and D-glucose to HMF in the presence of soluble metal salts in water.

\begin{tabular}{|c|c|c|c|c|c|c|c|}
\hline Substrate & $\mathrm{C}_{\text {sugar, }}(\mathrm{M})$ & Catalysts & Conditions & $\mathrm{X}_{\mathrm{C6} \text {-sugar }}{ }^{\mathrm{d}}$ & YHMFmax (mol \%) & Other Products & Ref. \\
\hline \multicolumn{8}{|c|}{ Monophasic (water) } \\
\hline Fructose & 0.3 & $\mathrm{ZnCl}_{2} / \mathrm{HCl}=1 / 1 \mathrm{~mol} / \mathrm{mol}$ & $120^{\circ} \mathrm{C}, 0-500 \mathrm{~min}$ & 97.3 & 53.3 & humins & {$[22]$} \\
\hline Fructose & 0.5 & $\mathrm{AlCl}_{3}(0.17 \mathrm{M}) / \mathrm{HCl}(1 \mathrm{M})$ & $88^{\circ} \mathrm{C}, 0-500 \mathrm{~min}$ & 60 & 20 & LA (45\%), humins & [23] \\
\hline Fructose & 0.3 & $\mathrm{DyCl}_{3} 2 \mathrm{mM}$ & $140^{\circ} \mathrm{C}, 120 \mathrm{~min}$ & $\mathrm{n} / \mathrm{a}$ & $<1$ & humins, LA & [24] \\
\hline Fructose & $5^{\mathrm{a}}$ & $\mathrm{AlCl}_{3} 50 \mathrm{~mol} \%$ & $120^{\circ} \mathrm{C}, 20 \mathrm{~min}$ & $\mathrm{n} / \mathrm{a}$ & 55.7 & LA, FA, humins & {$[25]$} \\
\hline Fructose & $30^{\mathrm{a}}$ & $\mathrm{AlCl}_{3} 0.87 \mathrm{M} /$ Boric acid $100 \mathrm{~g} \cdot \mathrm{L}^{-1}$ & $150^{\circ} \mathrm{C}, 45 \mathrm{~min}$ & 100 & $21^{\mathrm{a}}$ & LA, FA, humins & [26] \\
\hline Fructose & $30^{\mathrm{a}}$ & $\mathrm{FeCl}_{3} 0.87 \mathrm{M} /$ Boric acid $100 \mathrm{~g} \cdot \mathrm{L}^{-1}$ & $150^{\circ} \mathrm{C}, 45 \mathrm{~min}$ & 99 & $36^{\mathrm{a}}$ & LA, FA, humins & [26] \\
\hline Fructose & $30^{\mathrm{a}}$ & $\mathrm{MgCl}_{2} 0.87 \mathrm{M} /$ Boric acid $100 \mathrm{~g} \cdot \mathrm{L}^{-1}$ & $150^{\circ} \mathrm{C}, 45 \mathrm{~min}$ & 81 & $52^{\mathrm{a}}$ & LA, FA, humins & [26] \\
\hline Fructose & $10^{\mathrm{a}}$ & $\mathrm{CaP}_{2} \mathrm{O}_{6} 10$ wt. \% & $200^{\circ} \mathrm{C}, 5 \mathrm{~min}$ & 82 & $34^{\mathrm{a}}$ & $\mathrm{n} / \mathrm{a}$ & [27] \\
\hline Fructose & $10^{\mathrm{a}}$ & $\alpha-\operatorname{Sr}\left(\mathrm{PO}_{3}\right)_{2} 10$ wt. $\%$ & $200^{\circ} \mathrm{C}, 5 \mathrm{~min}$ & 88 & $39^{\mathrm{a}}$ & $\mathrm{n} / \mathrm{a}$ & [27] \\
\hline Fructose & $10^{\mathrm{a}}$ & $\mathrm{CrCl}_{3}$ & $140{ }^{\circ} \mathrm{C}, 60 \mathrm{~min}$ & 87 & 20 & LA ( $17 \%$ at $180 \mathrm{~min})$ & [28] \\
\hline Fructose & $10^{\mathrm{a}}$ & $\mathrm{CrCl}_{3}-\mathrm{HCl}$ & $140{ }^{\circ} \mathrm{C}, 25 \mathrm{~min}$ & 82 & 30 & LA $(45 \%$ at $6 \mathrm{~h})$ & [28] \\
\hline Fructose & $5^{\mathrm{a}}$ & $\mathrm{InCl}_{3} 3$ wt. $\%$ & $180^{\circ} \mathrm{C}, 15 \mathrm{~min}$ & 100 & 79.5 & LA $(45 \%$ at $1 \mathrm{~h})$ & [29] \\
\hline \multicolumn{8}{|c|}{ Monophasic (water) } \\
\hline Glucose & 0.3 & $\mathrm{ZnCl}_{2} / \mathrm{HCl}=1 / 1 \mathrm{~mol} / \mathrm{mol}$ & $120^{\circ} \mathrm{C}, 0-500 \mathrm{~min}$ & 80.5 & 32.3 & humins & [22] \\
\hline Glucose & 0.3 & $\mathrm{DyCl}_{3} 2 \mathrm{mM}$ & $140{ }^{\circ} \mathrm{C}, 120 \mathrm{~min}$ & $\mathrm{n} / \mathrm{a}$ & $<1$ & char, LA & [24] \\
\hline Glucose & $5^{\mathrm{a}}$ & $\mathrm{AlCl}_{3} 50 \mathrm{~mol} \%$ & $120^{\circ} \mathrm{C}, 20 \mathrm{~min}$ & $\mathrm{n} / \mathrm{a}$ & 40.3 & LA, FA, humins & {$[25]$} \\
\hline Glucose & $10^{\mathrm{a}}$ & $\mathrm{CaP}_{2} \mathrm{O}_{6} 10$ wt. $\%$ & $220^{\circ} \mathrm{C}, 5 \mathrm{~min}$ & 70 & $20^{\mathrm{a}}$ & $\mathrm{n} / \mathrm{a}$ & [27] \\
\hline Glucose & $10^{\mathrm{a}}$ & $\alpha-\operatorname{Sr}\left(\mathrm{PO}_{3}\right)_{2} 10$ wt. $\%$ & $220^{\circ} \mathrm{C}, 5 \mathrm{~min}$ & 60 & $21^{\mathrm{a}}$ & $\mathrm{n} / \mathrm{a}$ & [27] \\
\hline Glucose & $10^{\mathrm{a}}$ & $\mathrm{CrCl}_{3}$ & $140{ }^{\circ} \mathrm{C}, 90 \mathrm{~min}$ & 78 & 18 & LA ( $17 \%$ at $180 \mathrm{~min})$ & [28] \\
\hline Glucose & $10^{\mathrm{a}}$ & $\mathrm{CrCl}_{3}-\mathrm{HCl}$ & $140^{\circ} \mathrm{C}, 50 \mathrm{~min}$ & 55 & 16 & LA $(42 \%$ at $6 \mathrm{~h})$ & [28] \\
\hline Glucose & $10^{\mathrm{a}}$ & $\mathrm{InCl}_{3} 3$ wt. $\%$ & $180^{\circ} \mathrm{C}, 10 \mathrm{~min}$ & 91.4 & 59.8 & LA ( $27 \%$ at $10 \mathrm{~min})$ & [29] \\
\hline Glucose & 0.1 & $\mathrm{CrSO}_{4}, 5 \mathrm{mM}$ & $140^{\circ} \mathrm{C}, 6 \mathrm{~h}$ & 13 & 13 & lactic acid $(<3 \%)$, LA $(13 \%)$, fructose $(<3 \%)$, humins ${ }^{\mathrm{c}}$ & [30] \\
\hline Glucose & 0.25 & $\mathrm{AlCl}_{3} \cdot 6 \mathrm{H}_{2} \mathrm{O}$ & $160{ }^{\circ} \mathrm{C}, 10 \mathrm{~min}$ & 98 & 22 & LA (10\%), lactic acid $(17 \%)$ & [31] \\
\hline Glucose & 0.25 & $\mathrm{AlCl}_{3} \cdot 6 \mathrm{H}_{2} \mathrm{O}$ & $160^{\circ} \mathrm{C}, 10 \mathrm{~min}, \mathrm{H}_{2} \mathrm{O}-\mathrm{NaCl}$ & 98 & 17 & LA $(29 \%)$ & [31] \\
\hline Glucose & $5^{\mathrm{a}}$ & $\mathrm{MgCl}_{2} 0.8 \mathrm{M}$ & $160^{\circ} \mathrm{C}, 70 \mathrm{~min}$ & 15.6 & 3.9 & $\mathrm{n} / \mathrm{a}$ & [32] \\
\hline Glucose & $5^{\mathrm{a}}$ & $\mathrm{MgSO}_{4} 0.8 \mathrm{M}$ & $160^{\circ} \mathrm{C}, 70 \mathrm{~min}$ & 45.1 & 7.7 & $\mathrm{n} / \mathrm{a}$ & [32] \\
\hline Glucose & $5^{\mathrm{a}}$ & $\mathrm{NaCl}(0.8 \mathrm{M})-\mathrm{HCl}$ & $160^{\circ} \mathrm{C}, 70 \mathrm{~min}$ & 13.4 & 3.3 & $\mathrm{n} / \mathrm{a}$ & [32] \\
\hline
\end{tabular}


Table 1. Cont.

\begin{tabular}{|c|c|c|c|c|c|c|c|}
\hline Substrate & $\mathrm{C}_{\text {sugar, }}(\mathrm{M})$ & Catalysts & Conditions & $X_{\text {C6-sugar }}{ }^{d}$ & YHMFmax $_{\text {(mol \%) }}$ & Other Products & Ref. \\
\hline \multicolumn{8}{|c|}{ Monophasic/water } \\
\hline Glucose & $5^{\mathrm{a}}$ & $\mathrm{KCl}(0.8 \mathrm{M})-\mathrm{HCl}$ & $160^{\circ} \mathrm{C}, 70 \mathrm{~min}$ & 14.4 & 3.4 & $\mathrm{n} / \mathrm{a}$ & {$[32]$} \\
\hline Glucose & $5^{\mathrm{a}}$ & $\mathrm{MgCl}_{2}(0.8 \mathrm{M})-\mathrm{HCl}$ & $160^{\circ} \mathrm{C}, 70 \mathrm{~min}$ & 11.1 & 2.7 & $\mathrm{n} / \mathrm{a}$ & {$[32]$} \\
\hline Glucose & $5^{\mathrm{a}}$ & $\mathrm{CaCl}_{2}(0.8 \mathrm{M})-\mathrm{HCl}$ & $160^{\circ} \mathrm{C}, 70 \mathrm{~min}$ & 18 & 3.8 & $\mathrm{n} / \mathrm{a}$ & {$[32]$} \\
\hline Glucose & $10^{\mathrm{a}}$ & $\mathrm{CrCl}_{2}, 12 \mathrm{~mol} \%$ & $120^{\circ} \mathrm{C}, 3 \mathrm{~h}$ & 65 & $<3 \%$ & humins & {$[33]$} \\
\hline Glucose & $10^{\mathrm{a}}$ & $\mathrm{AlCl}_{3}, 12 \mathrm{~mol} \%$ & $120^{\circ} \mathrm{C}, 3 \mathrm{~h}$ & 74 & $<3 \%$ & humins & [33] \\
\hline Glucose & $10^{\mathrm{a}}$ & $\mathrm{FeCl}_{3}, 12 \mathrm{~mol} \%$ & $120^{\circ} \mathrm{C}, 3 \mathrm{~h}$ & 7 & 0 & humins & {$[33]$} \\
\hline Glucose & $10^{\mathrm{a}}$ & $\mathrm{CuCl}_{2}, 12 \mathrm{~mol} \%$ & $120^{\circ} \mathrm{C}, 3 \mathrm{~h}$ & 4 & 0 & humins & {$[33]$} \\
\hline Glucose & 0.2 & $\mathrm{CrCl}_{3} \cdot 6 \mathrm{H}_{2} \mathrm{O}, 12 \mathrm{~mol} \%$ & $140^{\circ} \mathrm{C}, 1 \mathrm{~h}, 80$ bar & 99 & $13 \%$ & LA (13\%) & [34] \\
\hline Glucose & 0.2 & $\mathrm{AlCl}_{3} \cdot 6 \mathrm{H}_{2} \mathrm{O}, 12 \mathrm{~mol} \%$ & $140^{\circ} \mathrm{C}, 1 \mathrm{~h}, 80$ bar & 88 & $19 \%$ & LA $(6 \%)$ & [34] \\
\hline Glucose & 0.2 & $\mathrm{ZrCl}_{4}, 12 \mathrm{~mol} \%$ & $140^{\circ} \mathrm{C}, 1 \mathrm{~h}, 80$ bar & 69 & $5 \%$ & LA (13\%) & [34] \\
\hline Glucose & 0.2 & $\mathrm{CuCl}_{2} \cdot 2 \mathrm{H}_{2} \mathrm{O}, 12 \mathrm{~mol} \%$ & $140^{\circ} \mathrm{C}, 1 \mathrm{~h}, 80 \mathrm{bar}$ & 23 & $6 \%$ & LA $(2 \%)$ & {$[34]$} \\
\hline Glucose & 0.2 & $\mathrm{BiCl}_{3}, 12 \mathrm{~mol} \%$ & $140^{\circ} \mathrm{C}, 1 \mathrm{~h}, 80$ bar & 17 & $5 \%$ & LA $(3 \%)$ & [34] \\
\hline Glucose & 0.2 & $\mathrm{FeCl}_{3} \cdot 6 \mathrm{H}_{2} \mathrm{O}, 12 \mathrm{~mol} \%$ & $140^{\circ} \mathrm{C}, 1 \mathrm{~h}, 80$ bar & 12 & $3 \%$ & LA $(0 \%)$ & {$[34]$} \\
\hline Glucose & 0.2 & $\mathrm{MgCl}_{2}, 12 \mathrm{~mol} \%$ & $140^{\circ} \mathrm{C}, 1 \mathrm{~h}, 80 \mathrm{bar}$ & 22 & $0.8 \%$ & LA $(0 \%)$ & [34] \\
\hline \multicolumn{8}{|c|}{ Biphasic } \\
\hline Glucose & $10^{\mathrm{a}}$ & $\mathrm{CrCl}_{3}-\mathrm{HCl}$ & $140^{\circ} \mathrm{C}, 180 \mathrm{~min}, \mathrm{THF}$ & 97 & 59 & LA (5\% at $180 \mathrm{~min})$ & {$[28]$} \\
\hline Glucose & 0.25 & $\mathrm{AlCl}_{3} .6 \mathrm{H}_{2} \mathrm{O}$ & $160^{\circ} \mathrm{C}, 10 \mathrm{~min}, \mathrm{H}_{2} \mathrm{O} / \mathrm{THF}$ & 99 & 52 & LA (trace), Lactic acid (13\%) & [31] \\
\hline Glucose & 0.25 & $\mathrm{AlCl}_{3} \cdot 6 \mathrm{H}_{2} \mathrm{O}$ & $160^{\circ} \mathrm{C}, 10 \mathrm{~min}, \mathrm{H}_{2} \mathrm{O}-\mathrm{NaCl} / \mathrm{THF}$ & 99 & 61 & LA (1\%) & [31] \\
\hline Glucose & $5^{\mathrm{a}}$ & $\mathrm{AlCl}_{3}-\mathrm{HCl}$ & $170^{\circ} \mathrm{C}, 40 \mathrm{~min}, \mathrm{SBP}{ }^{\mathrm{b}}$ & 91 & 62 & LA & {$[35]$} \\
\hline Glucose & $5^{\mathrm{a}}$ & $\mathrm{VCl}_{3}-\mathrm{HCl}$ & $170^{\circ} \mathrm{C}, 90 \mathrm{~min}, \mathrm{SBP}{ }^{\mathrm{b}}$ & 92 & 49 & LA & {$[35]$} \\
\hline Glucose & $5^{\text {a }}$ & $\mathrm{GaCl}_{3}-\mathrm{HCl}$ & $170^{\circ} \mathrm{C}, 2 \mathrm{~h}, \mathrm{SBP}{ }^{b}$ & 90 & 45 & LA & {$[35]$} \\
\hline Glucose & $5^{\text {a }}$ & $\mathrm{InCl}_{3}-\mathrm{HCl}$ & $170^{\circ} \mathrm{C}, 150 \mathrm{~min}, \mathrm{SBP}{ }^{b}$ & 86 & 45 & LA & {$[35]$} \\
\hline Glucose & $5^{\mathrm{a}}$ & $\mathrm{YbCl}_{3}-\mathrm{HCl}$ & $170^{\circ} \mathrm{C}, 2 \mathrm{~h}, \mathrm{SBP}^{\mathrm{b}}$ & 93 & 43 & LA & {$[35]$} \\
\hline Glucose & $5^{\mathrm{a}}$ & $\mathrm{DyCl}_{3}-\mathrm{HCl}$ & $170^{\circ} \mathrm{C}, 160 \mathrm{~min}, \mathrm{SBP}^{\mathrm{b}}$ & 93 & 38 & LA & {$[35]$} \\
\hline Glucose & $5^{\mathrm{a}}$ & $\mathrm{SnCl}_{4}-\mathrm{HCl}$ & $170^{\circ} \mathrm{C}, 45 \mathrm{~min}, \mathrm{SBP}{ }^{\mathrm{b}}$ & 90 & 52 & LA & {$[35]$} \\
\hline
\end{tabular}

${ }^{\mathrm{a}}$ in wt. \%; ${ }^{\mathrm{b}} 2$-sec-butylphenol; ${ }^{\mathrm{c}}$ water is one of the solvents ${ }^{\mathrm{d}} \mathrm{X}$ is the conversion of the $\mathrm{C} 6$ sugar, defined as the (initial concentration of the C6-sugar minus the concentration at time $=t) /($ initial concentration of the C6-sugar $) . \mathrm{LA}=$ levulinic acid; FA $=$ Formic acid; THF $=$ tetrahydrofuran; $\mathrm{SBP}=2$-sec-butylphenol. 
The metal salts described in Table 1 can be classified as water-compatible and water-sensitive compounds [36]. Well-known examples of water-compatible metal salts are lanthanide triflates like $\mathrm{Y}(\mathrm{OTf})_{3}$ and $\mathrm{La}(\mathrm{OTf})_{3}$. When dissolved in water, the metal ions catalyse important chemical transformations by acting as a strong Lewis acid. In contrast, water-sensitive metal salts based on Al, $\mathrm{Sn}, \mathrm{Fe}, \mathrm{Ga}$, and In are hydrolysed in water to various mono- and oligomeric species, and the formation of solutions with a $\mathrm{pH}<7$. As such, these water-sensitive metal salts in water may act both as a Brönsted and a Lewis acid [34].

We here report an experimental study on the conversion of inulin, a D-fructose-rich oligomer, to HMF in water using a range of water-soluble metal salts. This study complements earlier research in our group on the conversion of inulin to HMF [37]. Inulin is a biopolymer consisting mainly of D-fructose and minor amounts of D-glucose (Figure 1). It is present in jerusalem artichoke tubers, chicory roots, camas bulbs, and dahlia tubers, with inulin contents of around 15-20 wt. \% of fresh weight [38,39]. As such, it is an attractive biopolymer for the synthesis of $\mathrm{HMF}$.

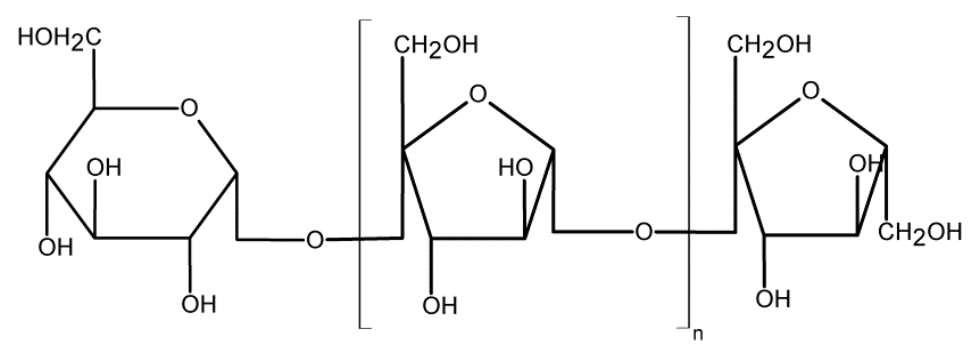

Figure 1. Inulin structure.

A number of studies have been reported on the synthesis of HMF from inulin in water [40-44]. The highest HMF yields reported so far in a monophasic system are from $\mathrm{Wu}$ et al. [40], who reported a 53\% HMF yield when performing the reaction in water in the presence of $\mathrm{CO}_{2}(11 \mathrm{MPa})$ at $200{ }^{\circ} \mathrm{C}$. Further improvements to 70\% HMF were reported by Benvenuti et al. [41] using a solid acid catalyst in combination with a biphasic system consisting of methyl-isobutyl-ketone (MIBK) and water. The latter is known to have a very positive effect on HMF yields. Recently, Muzart et al. reported HMF synthesis from inulin in DMSO without the use of a catalyst, and a 47\% yield of HMF was reported [44]. However, to the best of our knowledge, the use of metal salts for the conversion of inulin to HMF has not been reported to date. In this contribution, a number of metal salts were screened in water only and the best was selected for a more systematic study to probe the effects of process conditions on HMF yield. Finally, an experimental design study was initiated to quantify the effects of process conditions on HMF yield.

\section{Results and Discussion}

\subsection{Inulin Characterisation}

The molecular weight distribution of the inulin used in this study, which originates from Dahlia tubers, was determined by Matrix-assisted laser desorption/ionization time-of-flight mass spectrometry (MALDI-TOF/MS), a technique particularly suited for oligosaccharides and polysaccharides [45-47]. The Mn value was 2560, and the Mw was 3676, indicating an average degree of polymerisation (DP) of 
about 16. Roberfroid [47] reported that the DP of inulin varies according to plant species, weather conditions, and the physiological age of the plant. In chicory, the DP ranges from 2 to 65, but 15 is an average. For inulin from onions, the DP is in the range of 2-12, for Jerusalem artichoke the DP is reported to be $<40$. Thus, the DP of the Dahlia tuber sample used in this study is within the ranges reported in the literature.

The D-fructose and D-glucose content was determined by a mild hydrolysis of the samples followed by HPLC analyses of the liquid state. The D-fructose content was $94 \%$ and a D-fructose to D-glucose ratio of 15:1 was obtained. Thus, the inulin sample contains mainly D-fructose, with each oligomer chain on average capped with a D-glucose molecule, in line with literature data [47].

\subsection{Catalyst Screening Experiments}

A number of homogeneous metal salts containing $\mathrm{Al}, \mathrm{Sn}, \mathrm{Fe}$, and $\mathrm{Cu}$ metal ions with chloride and sulphate anions were tested for the reaction of inulin to HMF. The screening experiments were conducted at $170{ }^{\circ} \mathrm{C}$, a fixed inulin intake of $0.1 \mathrm{~g} / \mathrm{mL}$ and a salt concentration of $5 \mathrm{mM}$. The yield of HMF was determined (HPLC) and the results are shown in Figure 2. Under these non-optimised conditions, the HMF yield varied between 18 and 30 wt. \% (23 and $38 \mathrm{~mol} \%$ ).

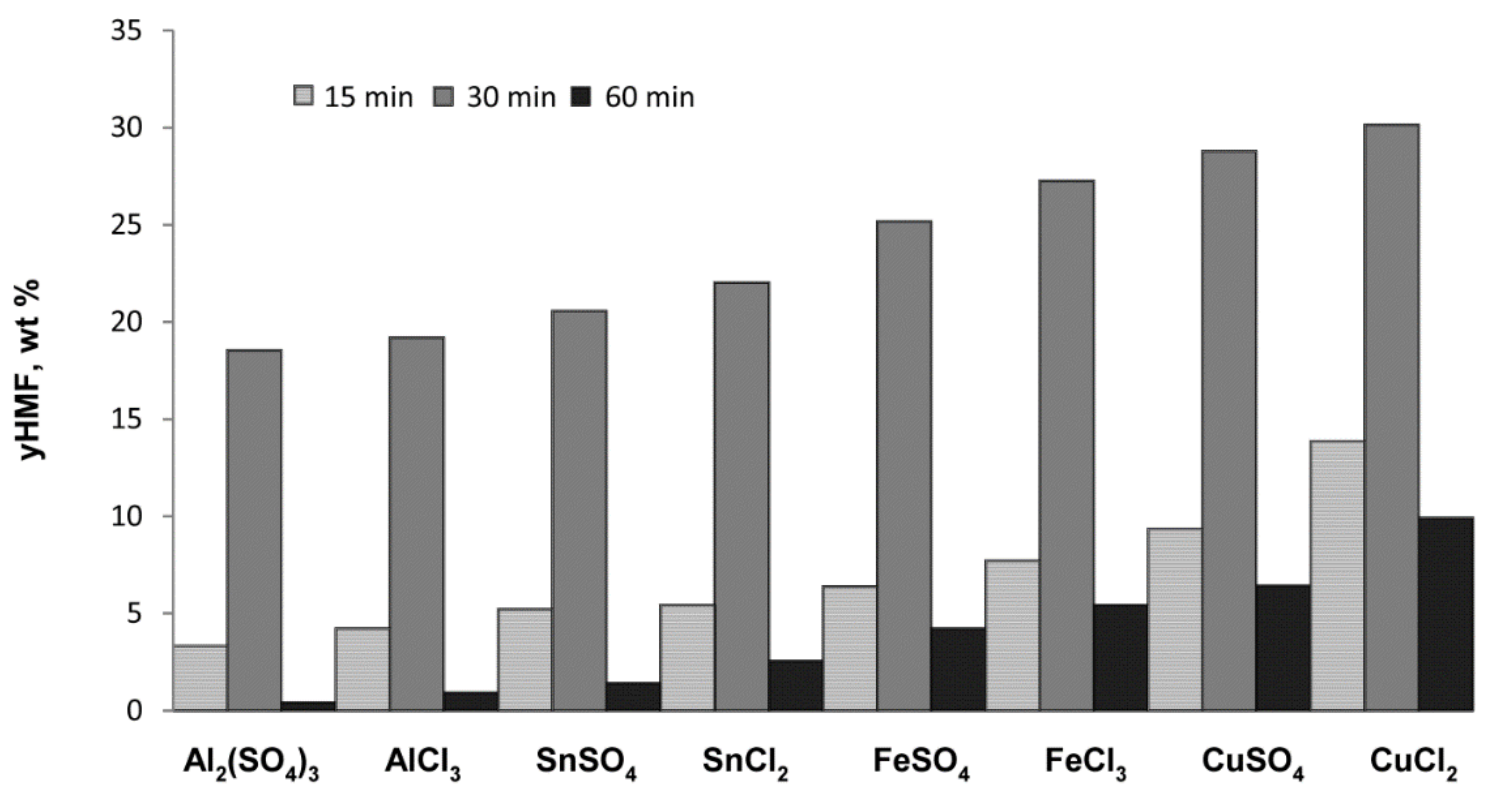

Figure 2. HMF yield as a function of the homogeneous metal salt catalyst $\left(170^{\circ} \mathrm{C}, 0.1 \mathrm{~g} / \mathrm{mL}\right.$ inulin, salt concentration of $5 \mathrm{mM}, 1 \mathrm{~h}$ ).

The best results were obtained for the $\mathrm{Cu}$ salts, whereas $\mathrm{Al}$ salts gave the worst results. In addition, the results for the sulphate anions were equal to those for the chloride anion, within the error of the experiment (see Table 2 and Section 2.5), an indication of the absence of strong anion effects. Catalyst performance of the metal salts is expected to be a function of the both the Brönsted and Lewis acidity of the solution. To gain some insight in the relative importance of both factors, the $\mathrm{pH}$ of all solutions was measured at room temperature and the results are shown in Table 2 and Figure 3. 
Table 2. $\mathrm{pH}$ of the solutions of the metal salts in water.

\begin{tabular}{cccccc}
\hline Salt & $\mathbf{p H}^{\mathbf{a}}$ & $\mathbf{Y}_{\mathbf{H M F}}$ (wt. \%) & Salt & $\mathbf{p H}^{\mathbf{a}}$ & $\mathbf{Y}_{\text {HMF (wt. \%) }}$ \\
\hline $\mathrm{Al}_{2}\left(\mathrm{SO}_{4}\right)_{3}$ & 4.04 & $18 \pm 1.5$ & $\mathrm{FeSO}_{4}$ & 2.90 & $25 \pm 1.5$ \\
$\mathrm{AlCl}_{3}$ & 4.34 & $19 \pm 1.5$ & $\mathrm{FeCl}_{3}$ & 2.96 & $27 \pm 1.5$ \\
$\mathrm{SnSO}_{4}$ & 2.97 & $21 \pm 1.5$ & $\mathrm{CuSO}_{4}$ & 5.54 & $28 \pm 1.5$ \\
$\mathrm{SnCl}_{2}$ & 3.11 & $22 \pm 1.5$ & $\mathrm{CuCl}_{2}$ & 5.71 & $30 \pm 1.5$ \\
\hline
\end{tabular}

${ }^{\mathrm{a}}$ Measured at room temperature, $5 \mathrm{mM}$ solution.

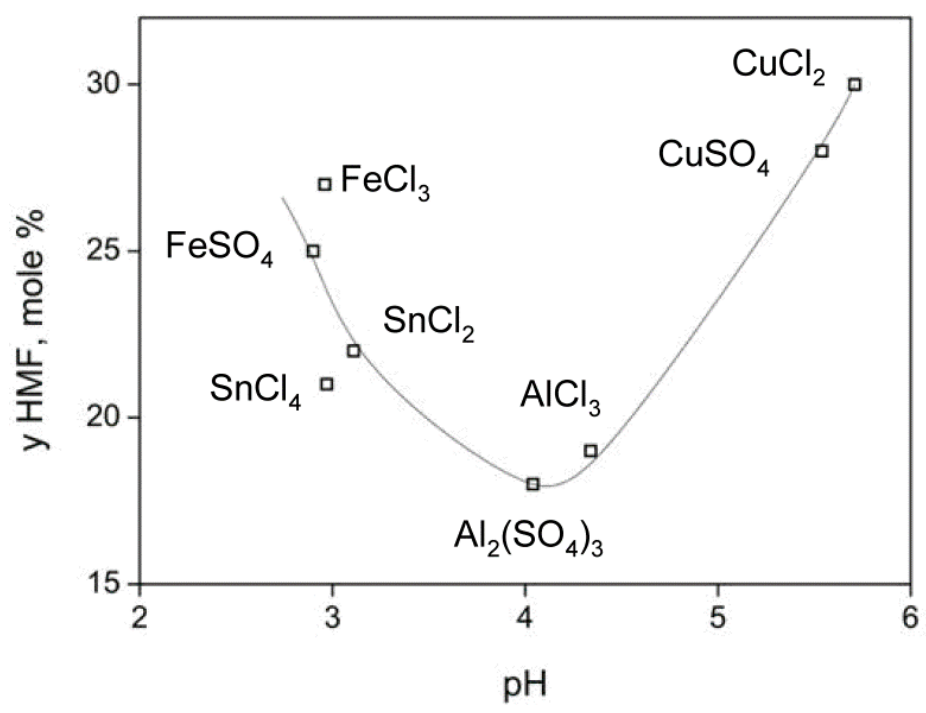

Figure 3. HMF yield versus the $\mathrm{pH}$ of the solution of the various metal salts in water $\left(170^{\circ} \mathrm{C}\right.$, inulin intake of $0.1 \mathrm{~g} / \mathrm{mL}, 5 \mathrm{mM}$ salt, $\left.30 \mathrm{~min}\right)$.

The HMF yield after $30 \mathrm{~min}$ is a function of the $\mathrm{pH}$ of the solution and shows a clear minimum at a $\mathrm{pH}$ of about 4 . All salts, except $\mathrm{Cu}$ salts, follow the same trend, that is, a higher $\mathrm{pH}$ leads to a lowering of the maximum HMF yield as well as the rate of HMF formation (Figures 2 and 3). Thus, it appears that the $\mathrm{H}^{+}$concentration plays a role in the rate of the reactions, with lower $\mathrm{pH}$ values leading to higher HMF yields after 30 min. Rationalisation of the data is difficult, as the maximum HMF yield is determined by the rate of at least three individual reactions (see the 3rd paragraph in Section 2.2), all with a different response regarding the $\mathrm{pH}$. However, it is clear that $\mathrm{Cu}$ salts are an exception in this trend. It shows the highest rate of HMF formation as well as the highest HMF yield within the series, despite that the $\mathrm{pH}$ of the solutions is by far the lowest. So far, we do not have a sound explanation for the good performance of $\mathrm{Cu}$ salts. One of the possibilities is that a $\mathrm{Cu}$ cation indeed acts as a Lewis acid and effectively catalyses the reaction of D-fructose to HMF without having a major effect on the subsequent reaction of HMF to LA, giving rise to the highest HMF yield. Aqueous solutions prepared from copper (II) chloride contain a range of copper (II) complexes, depending on concentration, temperature, and the presence of additional chloride ions. These include $\left.\mathrm{Cu}\left(\mathrm{H}_{2} \mathrm{O}\right)_{6}\right]^{2+}$ and halide complexes of the formula $\left[\mathrm{CuCl}_{2+x}\right]^{x^{-}}$, some of which may act as Lewis acids. Based on the results given in Figure 2, it is clear that copper (II) chloride gave the highest HMF yield and as a result this salt was selected for further (systematic) studies. 


\subsection{Exploratory Experiments on the Conversion of Inulin to $\mathrm{HMF}$ Using $\mathrm{CuCl}_{2}$}

Exploratory experiments on the conversion of inulin in the presence of $\mathrm{CuCl}_{2}$ in water were performed at $180{ }^{\circ} \mathrm{C}$, an inulin intake of $0.1 \mathrm{~g} / \mathrm{mL}$, and a $\mathrm{CuCl}_{2}$ concentration of $0.01 \mathrm{M}$. A typical concentration versus time profile for the main products is given in Figure 4.

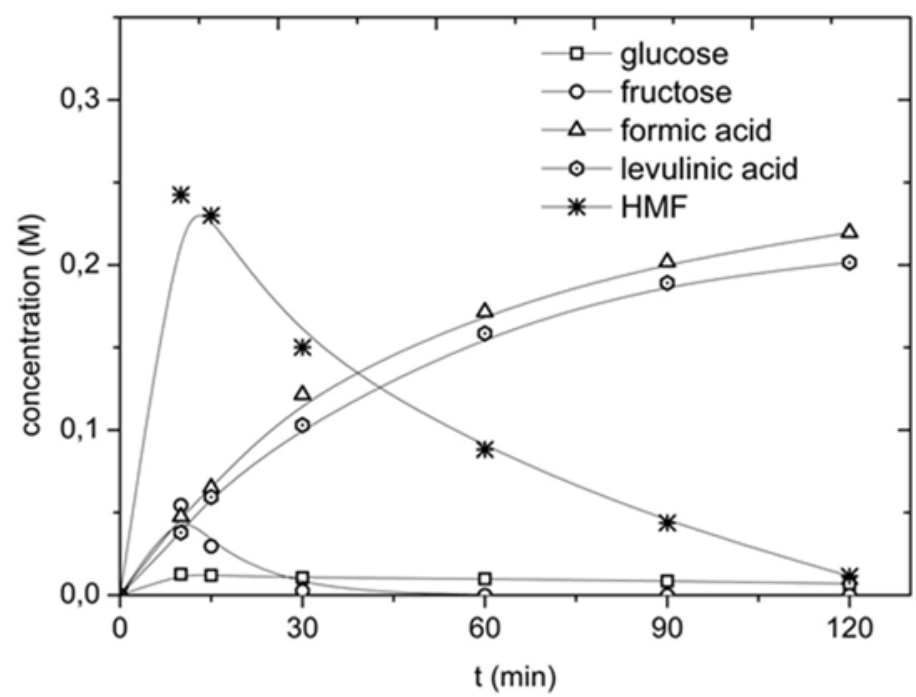

Figure 4. Concentration versus time profile for the reaction of inulin using $\mathrm{CuCl}_{2}$ $\left(\mathrm{T}=180^{\circ} \mathrm{C}, \mathrm{C}_{\mathrm{Cu}(\mathrm{II})}=0.01 \mathrm{M}, \mathrm{C}_{\text {inulin }}=0.1 \mathrm{~g} / \mathrm{mL}\right)$.

The main products in the course of the reaction are D-glucose, D-fructose, HMF, levulinic acid (LA), and formic acid (FA) (HPLC, Figure 5). Minor amounts of acetic acid and glyceraldehyde were also detected. D-fructose, D-glucose, and HMF are clearly intermediates in the reaction sequence and show an optimum in the concentration versus time profile. LA and FA are the final products.

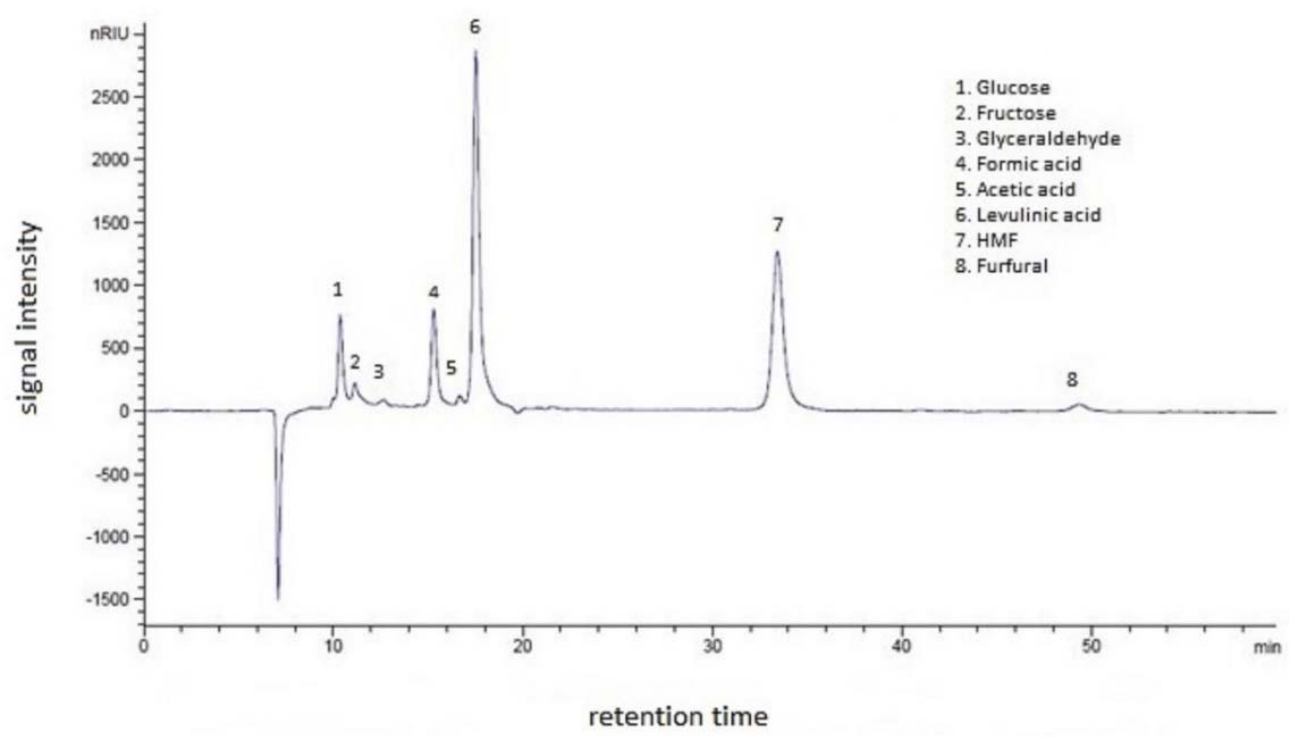

Figure 5. Typical HPLC spectrum of a reaction product of the reaction of inulin with $\mathrm{CuCl}_{2}$ in aqueous solutions. 
On the basis of the concentration versus time profile, a reaction network is proposed and given in Figure 6. The initial step involves hydrolysis of the inulin to D-fructose, D-glucose, and acetic acid. The latter is likely formed by the hydrolysis of minor amounts of acetyl groups present in the inulin [48]. This hydrolysis reaction is known to be catalysed by Brönsted acids, though Lewis acids have also been reported to be active $[49,50]$. Subsequently, both the D-fructose and D-glucose are dehydrated to HMF, which in a consecutive reaction is then rehydrated to LA and FA. At this stage, it is not clear whether the D-glucose converts to HMF directly or is first isomerized to D-fructose by the action of a Lewis acid like $\mathrm{Cu}^{2+}$ (tandem isomerization-dehydration) or directly to $\mathrm{HMF}$.

Although $\mathrm{CuCl}_{2}$ is reported to be a mediocre catalyst for the isomerization of D-glucose to D-fructose in water compared to, for instance, $\mathrm{AlCl}_{3}$ [34], our findings indicate that $\mathrm{CuCl}_{2}$ is a good active catalyst to promote HMF formation when D-fructose instead of D-glucose is used as the feedstock. It suggests that $\mathrm{Cu}$-salts are more active catalysts for the dehydration of D-fructose to HMF rather than for the D-glucose-fructose isomerisation reaction.

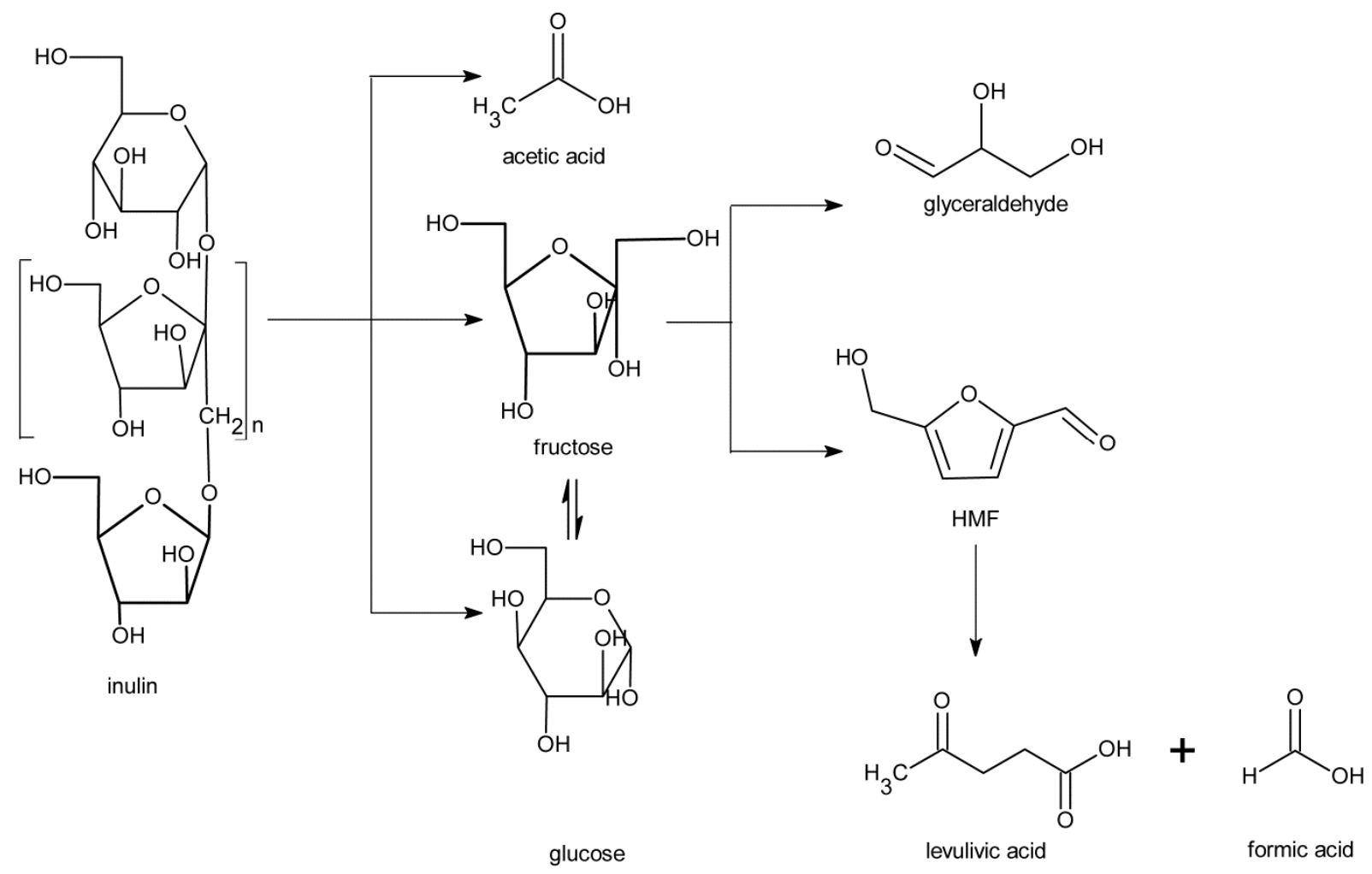

Figure 6. Proposed reaction network for inulin in copper (II) chloride solutions.

The minor product glyceraldehyde is likely formed from D-fructose via a retro-aldol condensation [30,48]. It is known to react further to pyruvaldehyde and subsequently to lactic acid [30,51-53]. Also, minor amounts of furfural are detected in the reaction and likely originate from D-fructose [48,51]. In addition, brown-black insolubles were formed, known as humins, which are always formed during catalytic conversions of carbohydrates in water [5,54]. 


\subsection{Effect of Process Conditions on HMF and LA Yields for Inulin Using $\mathrm{CuCl}_{2}$ Solutions}

To optimise the $\mathrm{HMF}$ yield for $\mathrm{CuCl}_{2}$, a number of experiments were carried out at a range of process conditions $\left(160-180{ }^{\circ} \mathrm{C}\right.$, inulin loading between $0.05-0.15 \mathrm{~g} / \mathrm{mL}, \mathrm{CuCl}_{2}$ concentrations between 0.005 and $0.015 \mathrm{M}$ ). The reactions were carried out in a microwave assisted batch reactor at different reaction times to obtain time-concentration profiles, with a maximum reaction time of $2 \mathrm{~h}$.

The effect of temperature on HMF and LA yield is shown in Figure 7 at a constant inulin intake $(0.1 \mathrm{~g} / \mathrm{mL})$ and catalyst concentration $(0.01 \mathrm{M})$. With regards to HMF yield, a maximum is observed and both the absolute value of this maximum and the time to reach the maximum yield are a function of temperature. As expected based on the proposed network in Figure 6, the optimum is observed at shorter reaction times when using higher temperatures. The maximum HMF yield is also highest for the highest temperature in the range, though the effect is not very pronounced (supported by subsequent modelling studies, see below). Rationalisation of this temperature effect on HMF yields is difficult, as HMF is formed by a number of consecutive reactions from inulin and is prone to further reactions, all with their own activation energies. In addition, humin byproducts are also formed, with temperature-dependant reaction rates.

The LA yield versus time profile is also a clear function of the temperature, with higher temperatures leading to higher LA yields (Figure 7). However, it is not possible to determine the temperature at which the LA yield is at its maximum, as not all of the HMF has been reacted to LA within the batch time of $2 \mathrm{~h}$.

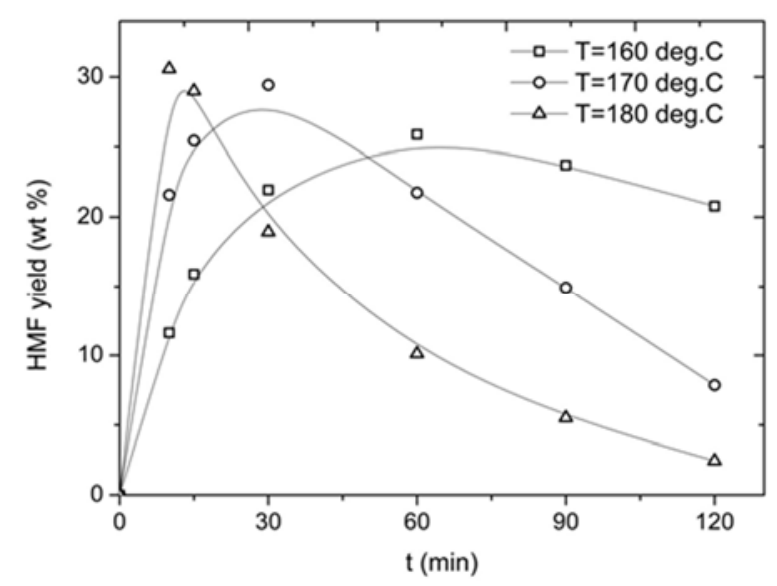

(a)

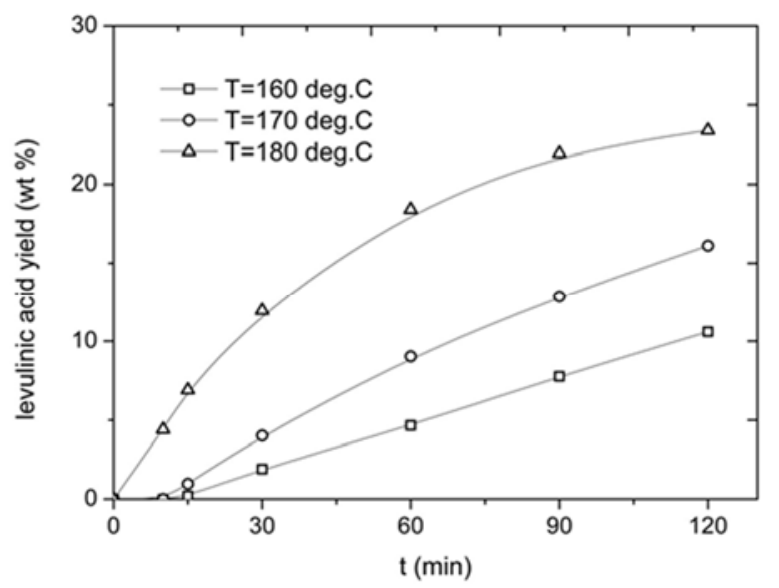

(b)

Figure 7. Yield of (a) $\mathrm{HMF}$ and (b) LA versus time at different temperatures $\left(C_{\text {inulin }}=0.1 \mathrm{~g} / \mathrm{mL}, C_{\mathrm{CuCl}_{2}}=0.01 \mathrm{M}\right)$.

The effect of the inulin intake on the yield of LA and HMF is shown in Figure 8 at a constant temperature of $180{ }^{\circ} \mathrm{C}$ and a catalyst concentration of $0.01 \mathrm{M}$. The HMF yield is a function of the intake, with higher intakes leading to lower HMF yields. These findings are in line with a kinetic study from our group on the reaction of D-fructose to HMF and LA using a Brönsted acid (sulphuric acid) [55]. This observation was rationalised by considering that the order of substrates for the reactions leading to humins is higher than those for the desired main reactions. As a consequence, dilution is favoured to enhance the yields of LA and HMF and to reduce polymerisation reactions. 
The LA yield is a clear function of the inulin intake with higher inulin intakes leading to higher yields. However, these data are not conclusive as the HMF and C6 sugar conversion are not yet quantitative after $2 \mathrm{~h}$ reaction time.

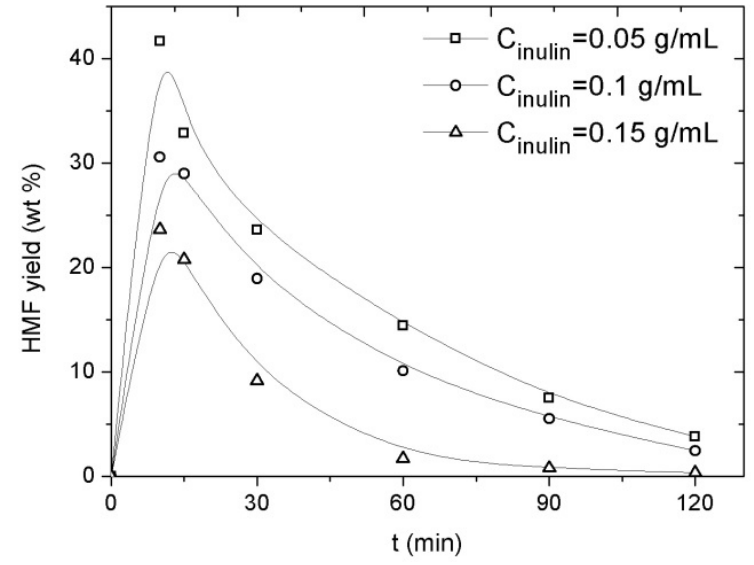

(a)

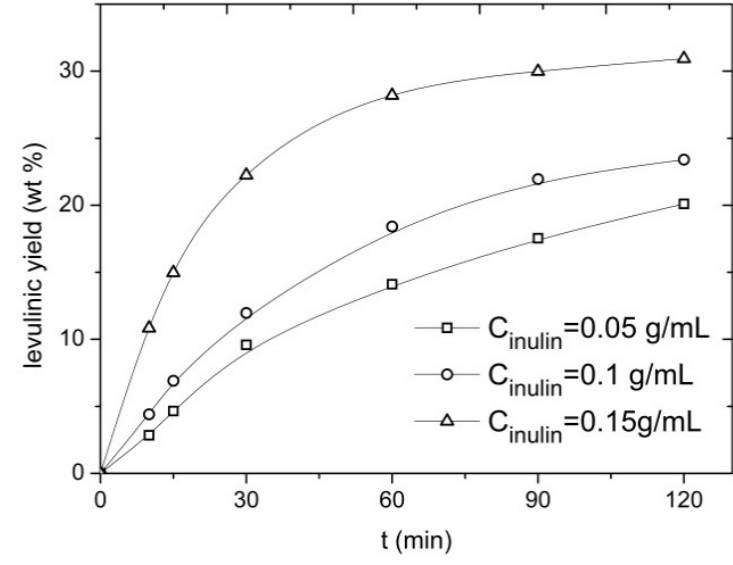

(b)

Figure 8. (a) HMF and (b) LA yield versus the time at various inulin intakes $\left(T=180{ }^{\circ} \mathrm{C}\right.$, $\left.\mathrm{C}_{\mathrm{CuCl} 2}=0.01 \mathrm{M}\right)$.

The effect of $\mathrm{CuCl}_{2}$ concentration on both the HMF and LA yield is shown in Figure $9\left(180^{\circ} \mathrm{C}\right.$, inulin intake of $0.1 \mathrm{~g} / \mathrm{mL}$ ). As expected, the catalyst has a positive effect on the reaction rates. For instance, the HMF conversion is about quantitative after $2 \mathrm{~h}$ reaction time at the highest catalyst concentration, whereas it is considerably lower for the lowest catalyst concentration. The maximum HMF yield is also a function of the catalyst concentration and it appears that a higher catalyst concentration has a negative effect on the maximum attainable HMF yield. This suggests that the order in catalyst concentration is not equal for all reactions in the network.

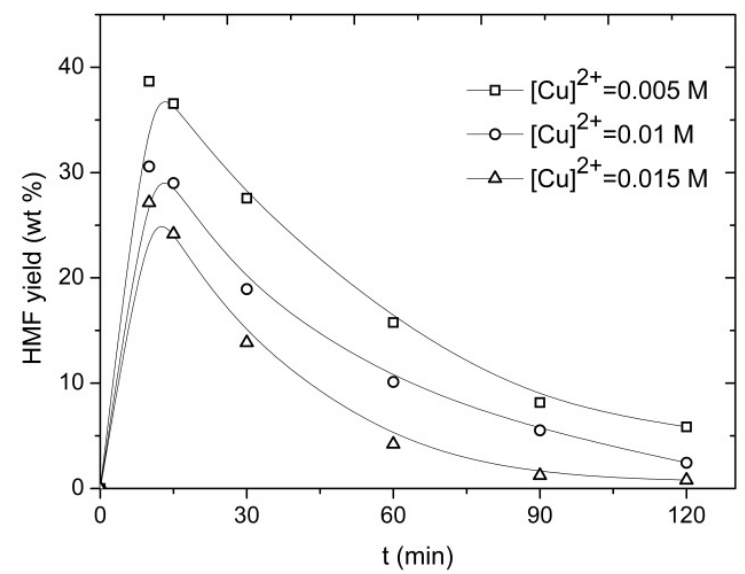

(a)

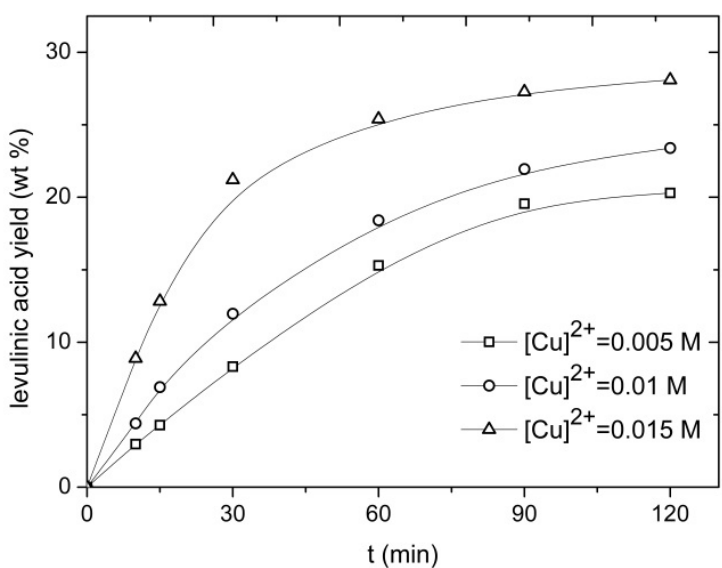

(b)

Figure 9. (a) $\mathrm{HMF}$ and (b) $\mathrm{LA}$ yield versus the time at various $\mathrm{CuCl}_{2}$ concentrations $\left(T=180{ }^{\circ} \mathrm{C}, C_{\text {inulin }}=0.1 \mathrm{~g} / \mathrm{mL}\right)$.

A similar trend was observed for a detailed kinetic study by our group on the conversion of D-fructose to HMF/LA using sulphuric acid as the catalyst [55]. It is not possible to assess the effect of the catalyst 
concentration on the LA yield, as the HMF conversion is not yet quantitative for the longest batch time $(2 \mathrm{~h})$. However, tentatively, it appears that the highest catalyst concentration in the range gives the best LA yield. These findings are again in line with our kinetic study of the conversion of D-fructose to $\mathrm{HMF} / \mathrm{LA}$ where the highest LA yield was also obtained with the highest sulphuric acid concentration in the range $(1 \mathrm{M})$.

\subsection{Quantification of Process Conditions on HMF and LA Yield Using Experimental Design and Statistical Modelling}

A total of 30 experiments were performed at different reaction conditions using a central composite design to quantify the effect of process conditions on the HMF and LA yield. Independent variables were temperature, inulin intake, copper (II) chloride concentration, and reaction time. The dependent variables were the HMF and the LA yield (Table 3). The centre point was measured six times, giving an average HMF yield of 20.8 wt. \% and a standard deviation of 1.5 wt. \%. As such, the reproducibility was good. The highest experimental HMF yield within the range was $30 \mathrm{wt} . \%(38.5 \mathrm{~mol} \%)$ and was obtained at $180{ }^{\circ} \mathrm{C}$, an inulin intake of $0.05 \mathrm{~g} / \mathrm{mL}, \mathrm{a} \mathrm{CCu}^{2+}$ of $0.005 \mathrm{M}$, and $10 \mathrm{~min}$ reaction time. The HMF yield as a function of the processing parameters was modelled using multivariable regression using the Design-Expert 8 software. The data are best described with the model provided in Equation (1). The model includes both quadratic and interaction terms of the independent variables.

$$
\begin{aligned}
y_{\mathrm{HMF}} & =(0.46) T+(9258.19) \mathrm{C}_{\mathrm{cat}}+(1.46) t+(4.79) T \cdot C_{\mathrm{load}}+(7.23) C_{\mathrm{cat}} \cdot t-(889.226) C_{\mathrm{load}} \\
& -(48.76) T \cdot C_{\mathrm{cat}}-\left(8.26 \times 10^{-3}\right) T \cdot t-69701.60 C_{\mathrm{cat}}{ }^{2}-\left(1.83 \times 10^{-3}\right) t^{2}-53.94
\end{aligned}
$$

\begin{tabular}{|c|c|c|c|c|c|c|}
\hline Run & $\begin{array}{c}\text { Temperature } \\
\left(T,{ }^{\circ} \mathrm{C}\right) \\
\end{array}$ & $\begin{array}{l}\text { Inulin Intake } \\
\left(C_{\text {inulin, }}, \mathrm{g} / \mathrm{mL}\right)\end{array}$ & $\begin{array}{c}\mathrm{CuCl}_{2} \text { Concentration, } \\
\left(C_{\text {cat }}, \mathrm{M}\right) \\
\end{array}$ & $\begin{array}{c}\text { Reaction Time } \\
(t, \text { min })\end{array}$ & $y_{\text {HMF }}(w t . \%)^{a}$ & $y_{\mathrm{LA}}(\mathrm{wt} . \%)^{\mathrm{b}}$ \\
\hline 1 & 170 & 0.15 & 0.010 & 65 & 18.2 & 8.3 \\
\hline 2 & 160 & 0.15 & 0.005 & 10 & 9.8 & 1.4 \\
\hline 3 & 170 & 0.10 & 0.010 & 65 & 20.6 & 9.7 \\
\hline 4 & 170 & 0.10 & 0.010 & 10 & 21.6 & 3.0 \\
\hline 5 & 180 & 0.15 & 0.005 & 10 & 25.8 & 2.6 \\
\hline 6 & 160 & 0.05 & 0.015 & 10 & 23.5 & 5.2 \\
\hline 7 & 160 & 0.05 & 0.015 & 120 & 25 & 10.0 \\
\hline 8 & 160 & 0.05 & 0.005 & 10 & 19.7 & 6.3 \\
\hline 9 & 170 & 0.10 & 0.005 & 65 & 18.7 & 7.8 \\
\hline 10 & 170 & 0.10 & 0.010 & 65 & 23.0 & 13.1 \\
\hline 11 & 160 & 0.15 & 0.005 & 120 & 3.3 & 7.2 \\
\hline 12 & 180 & 0.10 & 0.010 & 65 & 18.4 & 19.0 \\
\hline 13 & 160 & 0.15 & 0.015 & 120 & 10 & 8.3 \\
\hline 14 & 170 & 0.10 & 0.010 & 120 & 7.9 & 16.1 \\
\hline 15 & 160 & 0.15 & 0.015 & 10 & 9.7 & 4.0 \\
\hline 16 & 170 & 0.10 & 0.010 & 65 & 19.0 & 9.7 \\
\hline 17 & 180 & 0.15 & 0.015 & 10 & 17.0 & 5.3 \\
\hline 18 & 180 & 0.05 & 0.015 & 10 & 21.4 & 9.8 \\
\hline 19 & 170 & 0.10 & 0.010 & 65 & 22.0 & 11.0 \\
\hline
\end{tabular}

Table 3. Overview of experiments for the reaction of inulin in water using $\mathrm{CuCl}_{2}$ as the catalyst. 
Table 3. Cont.

\begin{tabular}{|c|c|c|c|c|c|c|}
\hline Run & $\begin{array}{c}\text { Temperature } \\
\left(T,{ }^{\circ} \mathrm{C}\right) \\
\end{array}$ & $\begin{array}{l}\text { Inulin Intake } \\
\left(C_{\text {inulin }}, \mathrm{g} / \mathrm{mL}\right)\end{array}$ & $\begin{array}{c}\mathrm{CuCl}_{2} \text { Concentration, } \\
\left(C_{\mathrm{cat}}, \mathrm{M}\right)\end{array}$ & $\begin{array}{c}\text { Reaction Time } \\
(t, \mathrm{~min})\end{array}$ & $y_{\text {HMF }}(w t . \%)^{a}$ & $y_{\mathrm{LA}}(\text { wt. \%) })^{\mathrm{b}}$ \\
\hline 20 & 160 & 0.10 & 0.010 & 65 & 23.5 & 5.2 \\
\hline 21 & 160 & 0.05 & 0.005 & 120 & 13.6 & 4.7 \\
\hline 22 & 170 & 0.10 & 0.015 & 65 & 18.4 & 14.8 \\
\hline 23 & 180 & 0.15 & 0.005 & 120 & 1.0 & 21.6 \\
\hline 24 & 170 & 0.05 & 0.010 & 65 & 25.4 & 13.3 \\
\hline 25 & 170 & 0.10 & 0.010 & 65 & 20.7 & 10.7 \\
\hline 26 & 180 & 0.05 & 0.005 & 10 & 30.3 & 6.5 \\
\hline 27 & 180 & 0.05 & 0.015 & 120 & 2.0 & 28.9 \\
\hline 28 & 180 & 0.15 & 0.015 & 120 & 3.4 & 27.1 \\
\hline 29 & 170 & 0.10 & 0.010 & 65 & 19.9 & 10.6 \\
\hline 30 & 180 & 0.05 & 0.005 & 120 & 4.4 & 27.8 \\
\hline
\end{tabular}

${ }^{a}$ The yield of HMF is defined in Equation (3); ${ }^{b}$ The yield of LA is defined in Equation (4).

An extended version with more significant numbers for the coefficients to be used for among other reactor engineering studies is given in the supplementary information. The analysis of variance of the model is given in Table 4 . The R-squared value for the model is 0.9764 , indicating that the model fits the experimental data well. This is supported by a parity plot in Figure 10 showing the data and model points.

Table 4. Analysis of variance of the preferred model for the yield of HMF.

\begin{tabular}{cccccc}
\hline \multirow{2}{*}{ Source } & Sum of Squares & $\boldsymbol{d} \boldsymbol{f}$ & Mean Square & $\boldsymbol{F}$-value & $\boldsymbol{p}$-Value \\
\hline Model & 1831.98 & 10 & 183.20 & 78.50 & $<0.0001$ (significant) \\
A-T & 11.81 & 1 & 11.81 & 5.06 & 0.0365 \\
B-C $_{\text {load }}$ & 247.48 & 1 & 247.48 & 106.04 & $<0.0001$ \\
C-C $_{\text {cat. }}$ & 0.92 & 1 & 0.92 & 0.39 & 0.5373 \\
D-t & 647.07 & 1 & 647.07 & 277.25 & $<0.0001$ \\
AB & 91.95 & 1 & 91.95 & 39.40 & $<0.0001$ \\
AC & 95.09 & 1 & 95.09 & 40.74 & $<0.0001$ \\
AD & 330.29 & 1 & 330.29 & 141.52 & $<0.0001$ \\
CD & 63.23 & 1 & 63.23 & 27.09 & $<0.0001$ \\
$C^{2}$ & 10.46 & 1 & 10.46 & 4.48 & 0.0477 \\
$D^{2}$ & 106.06 & 1 & 106.06 & 45.45 & $<0.0001$ \\
Residual & 44.34 & 19 & - & - & - \\
\hline
\end{tabular}

The yield of HMF as a function of the process conditions as predicted by the model is given in Figure 11. Clearly, the reaction time has a profound effect on the HMF yield, rationalised by assuming that HMF is an intermediate in the reaction sequence and ultimately will be converted to LA. Due to the interactions between the independent variables, it is difficult to draw general conclusions regarding the effect of individual independent variables on HMF yield. 


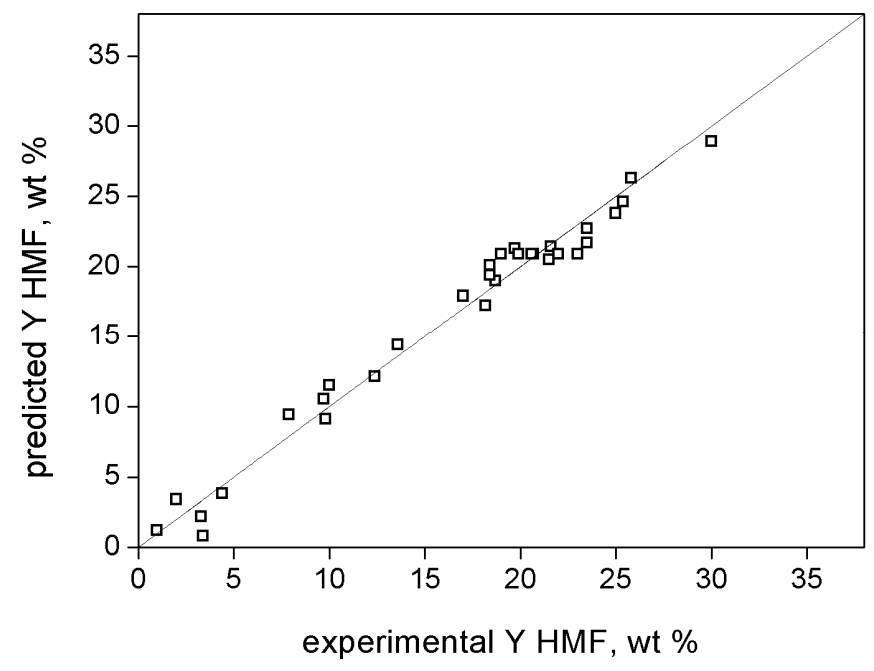

Figure 10. Parity plot for the HMF yield.

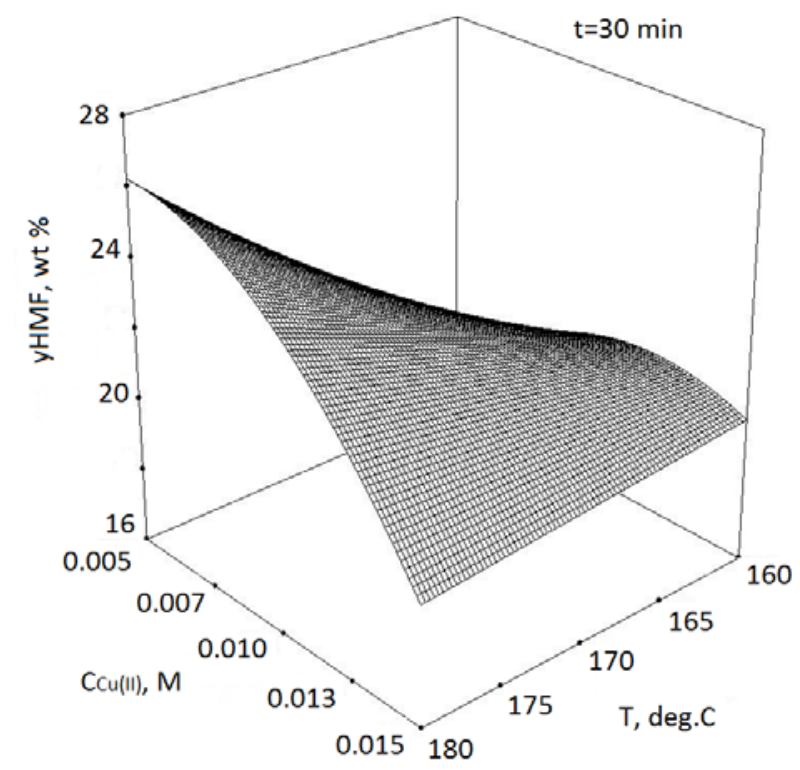

(a)

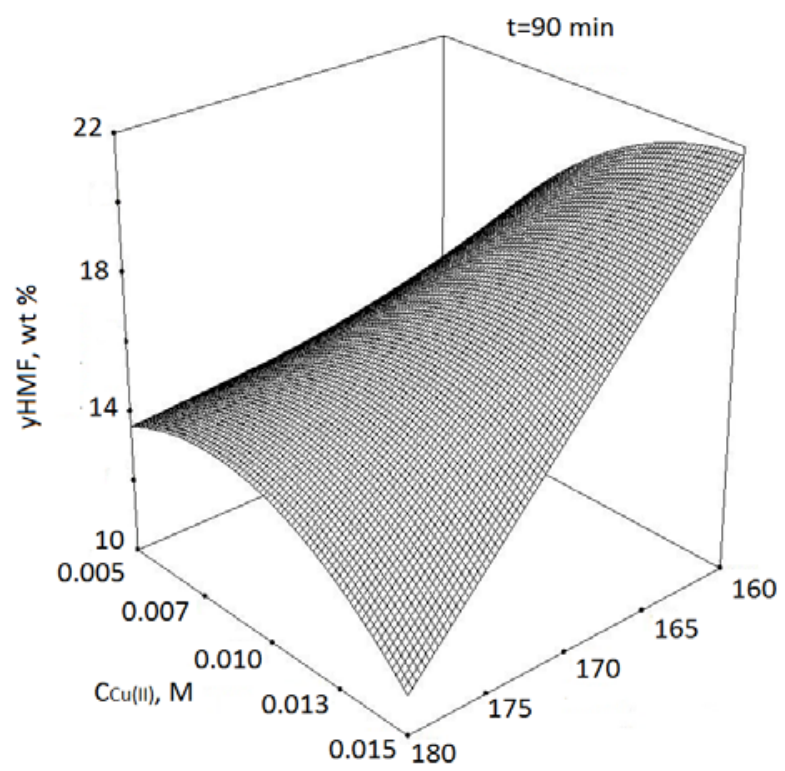

(b)

Figure 11. Modelled HMF yield versus temperature and inulin intake at (a) $30 \mathrm{~min}$ and (b) 90 min batch time.

The yield of LA as a function of the process conditions was also modelled, and the results are given in Table 5 and Equation (2). An extended version of Equation (2) with more significant numbers for the coefficients to be used among other reactor engineering studies is given in the supplementary information. The model describes the data points well, as is expressed by an $R$-squared value of 0.9651 and a parity plot (Figure 12).

$$
y_{\mathrm{LA}}=(0.17) T+(204.63) C_{\mathrm{load}}+(303.82) C_{\mathrm{cat}}-(1.2) t-(1.38) T \cdot C_{\mathrm{load}}+\left(7.73 \times 10^{-3}\right) T \cdot t-25.22
$$




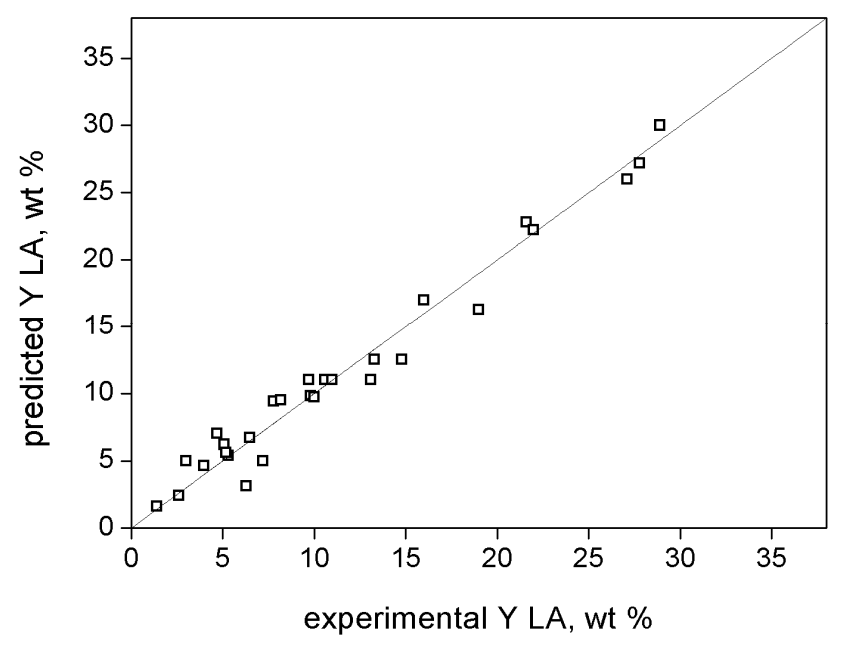

Figure 12. Parity plot for LA yield.

Table 5. Analysis of variance of the preferred model of LA.

\begin{tabular}{|c|c|c|c|c|c|}
\hline \multirow{2}{*}{ Source } & \multirow{2}{*}{ Sum of Squares } & \multirow{2}{*}{$d f$} & \multirow{2}{*}{ Mean Square } & \multirow{2}{*}{ F-Value } & $p$-Value \\
\hline & & & & & Prob $>F$ \\
\hline Model & 1538.79 & 6 & 256.47 & 106.20 & $<0.0001$ (significant) \\
\hline A-T & 515.98 & 1 & 515.98 & 213.29 & $<0.0001$ \\
\hline B-C $\mathrm{C}_{\text {load }}$ & 39.77 & 1 & 39.77 & 16.44 & 0.0005 \\
\hline $\mathrm{C}-\mathrm{C}_{\text {cat. }}$ & 41.54 & 1 & 41.54 & 17.17 & 0.0004 \\
\hline$D-t$ & 644.84 & 1 & 644.84 & 266.56 & $<0.0001$ \\
\hline $\mathrm{AB}$ & 7.60 & 1 & 7.60 & 3.14 & 0.0895 \\
\hline $\mathrm{AD}$ & 289.06 & 1 & 289.06 & 119.49 & $<0.0001$ \\
\hline Residual & 55.64 & 23 & - & - & - \\
\hline
\end{tabular}

The effect of two process conditions (temperature and reaction time) is presented in Figure 13. The LA yield increases at higher temperatures and longer reaction times, in line with the proposed reaction network (Figure 6) where LA is the final product and HMF an intermediate.

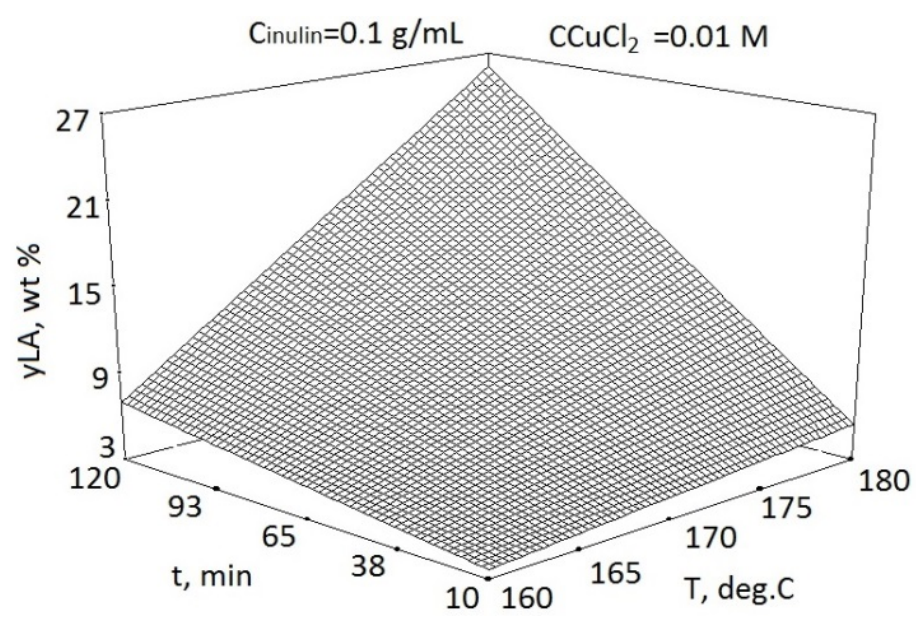

Figure 13. Modelled LA yield versus temperature and reaction time at a fixed inulin intake $(0.1 \mathrm{~g} / \mathrm{mL})$ and $\mathrm{CuCl}_{2}$ concentration $(0.01 \mathrm{M})$. 


\section{Experimental Section}

\subsection{Chemicals}

Inulin isolated from Dahlia tubers was purchased from Acros Organic (Geel, Belgium). D-fructose (99\%) and levulinic Acid ( $\geq 97 \%$ ) were obtained from Acros Organic (Geel, Belgium). Formic Acid and D-glucose were purchased from Merck KGaA (Darmstadt, Germany). 5-Hydroxymethylfurfural (HMF) ( $\geq 99 \%$ ) was obtained from Aldrich (Steinheim, Germany). Copper (II) chloride dihydrate ( $\geq 99 \%$ ) was bought from Acros Organics (Geel, Belgium). All other salts were obtained from Acros Organics (Geel, Belgium). All chemicals were used without purification. Deionized water was used to prepare the solutions.

\subsection{Experimental Procedures}

\subsubsection{Catalyst Screening Experiments}

For the catalyst screening experiments, $2 \mathrm{~mL}$ of a solution of inulin ( $0.2 \mathrm{~g}$ inulin) and the metal salt $(5 \mathrm{mM})$ in water was placed in a microwave tube. The tube was sealed with a plastic cap and placed in the microwave device (CEM Synthesis Explorer 48, CEM, Matthews, NC, USA), heated to $170{ }^{\circ} \mathrm{C}$, and stirred for $1 \mathrm{~h}$ at this temperature. After reaction, the tube was rapidly cooled; the contents were filtered, and the liquid phase was analysed by HPLC.

\subsubsection{Experimental Design Experiments}

A similar experimental procedure as for the screening experiments was applied; the only difference being that solely copper (II) chloride was used as the catalyst. In addition, a broad window of process variables was used, viz temperatures in the range of $160-180{ }^{\circ} \mathrm{C}$, initial inulin loadings in the range of $0.05-0.15 \mathrm{~g} / \mathrm{mL}$, copper (II) chloride concentrations between $0.005-0.015 \mathrm{M}$, and reaction times between 10 and $120 \mathrm{~min}$.

\subsection{Analyses}

HPLC was used to identify and quantify the components in the liquid product after reaction. An Agilent technologies (Santa Clara, CA, USA), 1200 series HPLC equipped with an isocratic pump, a Bio-Rad (Hercules, CA, USA) Aminex HPX-87H organic acid column (300 mm $\times 7.8 \mathrm{~mm}$ ), and a Waters (Milford, MA, USA) 410 differential refractive index detector was used. Sulfuric acid in water $(5 \mathrm{mM})$ was used as the eluent with a constant flow rate of $0.55 \mathrm{~mL} / \mathrm{min}$. The column was operated at $60{ }^{\circ} \mathrm{C}$. The analysis time for each sample was $60 \mathrm{~min}$. The HPLC was calibrated with solutions of known compounds. Using the chromatogram peak area and the external calibration curve, the unknown concentrations of components in the liquid phase were determined.

MALDI-TOF/MS on a Voyager-DE PRO (Applied Biosystems, Foster City, CA, USA) was used to determine the molecular weight of the inulin sample. 2,5-Dihydroxybenzoic acid (DHB) was used as the matrix. 
The composition of the inulin sample, particularly the type and amount of C6-sugars, was determined by an acid-catalysed hydrolysis reaction. For this purpose, inulin $(2.5 \mathrm{~g})$ was dissolved at $70{ }^{\circ} \mathrm{C}$ in $150 \mathrm{~mL}$ of water under stirring. The $\mathrm{pH}$ was adjusted to $1.4-1.6$ by adding an aqueous $\mathrm{HCl}$ solution. Then, the solution was placed in a water bath for $30 \mathrm{~min}$ at $90{ }^{\circ} \mathrm{C}$. A liquid sample was taken and analysed by HPLC.

\subsection{Definitions}

The HMF yield ( $\left.y_{\mathrm{HMF}}\right)$ is reported on a wt. \% basis and defined as follows:

$$
y_{\mathrm{HMF}}=\frac{C_{\text {НMF }} \times M_{\mathrm{HMF}} \times V}{W_{\ln }} \times 100 \%(\mathrm{~g} \mathrm{HMF} / \mathrm{g} \text { inulin intake })
$$

The yield of LA is defined as:

$$
y_{\mathrm{LA}}=\frac{C_{\mathrm{LA}} \times M_{\mathrm{LA}} \times V}{W_{\mathrm{ln}}} \times 100 \%(\mathrm{~g} \mathrm{LA} / \mathrm{g} \text { inulin intake })
$$

In Equations (3) and (4), $C_{H M F}$ and $C_{\mathrm{LA}}$ represent the concentration of HMF and LA, respectively (mol/L) as measured with HPLC, MHMF and MLA the molecular weight of HMF and LA ( $\mathrm{g} \cdot \mathrm{mol}), V$ the water intake $(\mathrm{L})$, and $W_{\text {in }}$ the intake of inulin on a weight basis $(\mathrm{g})$.

The yield of HMF was converted from wt. \% to mol \% by assuming that inulin consists of linked glucose/fructose units $\left(\mathrm{C}_{6} \mathrm{H}_{10} \mathrm{O}_{5}\right)$ which react to $\mathrm{HMF}$ according to the following stoichiometry:

$$
\mathrm{C}_{6} \mathrm{H}_{10} \mathrm{O}_{5} \rightarrow \mathrm{C}_{6} \mathrm{H}_{6} \mathrm{O}_{3}+2 \mathrm{H}_{2} \mathrm{O}
$$

As such, the maximum yield of HMF is $78 \mathrm{wt} . \%$. Thus, the yield of HMF in mol \% may be calculated from the yield in wt. \% by dividing the latter by 0.78 .

\subsection{Statistical Modelling}

The yield of HMF as a function of process variables was modelled using the Design-Expert 7 software package (Stat-Ease, Minneapolis, MN, USA) using a standard expression given in Equation (6):

$$
y_{\mathrm{HMF}}=b_{0}+\sum_{i=1}^{4} b_{i} x_{i}+\sum_{i=1}^{4} \sum_{j=1}^{4} b_{i j} x_{i} x_{j}
$$

The process variables ( $x_{i}$ : inulin intake, temperature, copper (II) chloride concentration, and reaction time) are represented by the indices $1-4$. The regression coefficients were obtained by statistical analyses of the data. Significance of factors was determined by their $p$-value in the ANOVA analyses. A factor was considered significant if the $p$-value is below 0.05 , meaning that the probability of noise causing the correlation between a factor and the response is lower than 0.05 . Insignificant factors were eliminated using backward elimination, and the significant factors were used to model the data.

\section{Conclusions}

An exploratory screening study revealed that metal salts may be used as catalysts for the reaction of inulin to $\mathrm{HMF}$ in water. Best results were obtained using $\mathrm{CuCl}_{2}$, giving an $\mathrm{HMF}$ yield of $30.3 \mathrm{wt}$ \% $\left(39 \mathrm{~mol} \%\right.$ ) at $180{ }^{\circ} \mathrm{C}, 0.05 \mathrm{~g}$ inulin/mL, a $0.005 \mathrm{M} \mathrm{CuCl}_{2}$ solution, and a reaction time of $10 \mathrm{~min}$. The 
special role of $\mathrm{Cu}^{2+}$ salts is likely due to the Lewis acidic character of $\mathrm{Cu}^{2+}$ and not due to catalysis by Brönsted acids $\left(\mathrm{H}^{+}\right)$. However, further investigations using model reactions with intermediates in the reaction sequence (D-fructose, $\mathrm{HMF}$ ) and $\mathrm{Cu}$ salts will be required to draw definite conclusions. In addition, it was also shown that metal salts with chloride anions and sulphate anions perform essentially similar, indicative of the absence of strong anion effects. This aspect also requires further attention and both findings may aid the development of more efficient catalysts for the conversion of the C6 sugar in biopolymers to HMF and levulinic acid in water.

\section{Acknowledgments}

B.A. Fachri would like to thank the Directorate General of Higher Education, Ministry of Education and Culture, Indonesia for funding of his $\mathrm{PhD}$ program.

\section{Author Contributions}

C.B.R and H.J.H conceived and designed the experiments, B.A.F performed the experiments, C.B.R, B.A.F. and H.J.H analyzed the data, B.A.F and H.J.H. wrote the paper.

\section{Conflicts of Interest}

The authors declare no conflict of interest.

\section{References}

1. Lichtenthaler, F.W.; Peters, S. Carbohydrates as green raw materials for the chemical. Comptes Rendus Chim. 2004, 7, 65-90.

2. Bozell, J.J.; Petersen, G.R. Technology development for the production of biobased products from biorefinery carbohydrates - The US department of energy's “top 10" revisited. Green Chem. 2010, 12, 539-554.

3. Wang, T.; Nolte, M.W.; Shanks, N.B. Catalytic dehydration of C6 carbohydrates for the production of Hydroxymethylfurfural (HMF) as a versatile platform chemical. Green Chem. 2014, 16, 548-572.

4. Ragauskas, A.J.; Williams, C.K.; Davison, B.H.; Britovsek, G.; Cairney, J.; Eckert, C.A.; Frederick, W.J., Jr.; Hallet, J.P.; Leak, D.J.; Liotta, C.L.; et al. The path forward for biofuels and biomaterials. Science 2006, 311, 484-489.

5. Van Putten, R.J.; van der Waal, J.C.; de Jong, E.; Rasrendra, C.B.; Heeres, H.J.; de Vries, J.G. Hydroxymethylfurfural, A versatile platform chemical made from renewable resources. Chem. Rev. 2013, 113, 1499-1597.

6. Sheldon, R.A. Green and sustainable manufacture of chemicals from biomass: State of the art. Green Chem. 2014, 16. 950-963.

7. Delidovich, I.; Leonhard, K.; Palkovits, R. Cellulose and hemicellulose valorisation: An integrated challenge of catalysis and reaction engineering. Energy Environ. Sci. 2014, 7, 2803-2830. 
8. Agirrezabal-Telleria, I.; Gandarias, I.; Arias, P.L. Heterogeneous acid-catalysts for the production of furan-derived compounds (furfural and hydroxymethylfurfural) from renewable carbohydrates: A Review. Catal. Today 2014, 234, 42-58.

9. Werpy, T.; Petersen, G. Top value added chemicals from biomass. Volume I-Results of screening for potential candidates from sugars and synthesis gas. Nat. Renew. Energy Lab. 2004, doi:10.2172/15008859.

10. Clark, J.H.; Budarin, V.; Deswarte, F.E.; Hardy, J.J.; Kerton, F.M.; Hunt, A.J.; Luque, R.; Macquarrie, D.J.; Milkowski, K.; Rodriguez, A.; et al. Green chemistry and the biorefinery: A partnership for a sustainable future. Green Chem. 2006, 8, 853-860.

11. Huber, G.W.; Iborra, S.; Corma, A. Synthesis of transportation fuels from biomass: Chemistry, catalysts, and engineering. Chem. Rev. 2006, 106, 4044-4098.

12. Petrus, L.; Noordermeer, M.A. Biomass to biofuels, a chemical perspective. Green Chem. 2006, 8, 861-867.

13. Corma, A.; Iborra, S.; Velty, A. Chemical routes for the transformation of biomass into chemicals. Chem. Rev. 2007, 107, 2411-2502.

14. Girisuta, B.; Danon, B.; Manurung, R.; Janssen, L.P.B.M.; Heeres, H.J. Experimental and kinetic modelling studies on the acid-catalysed hydrolysis of the water hyacinth plant to levulinic acid. Bioresour. Technol. 2008, 99, 8367-8375.

15. Hayes, D.J. An examination of biorefining processes, catalysts and challenges. Catal. Today 2009, $145,138-151$.

16. Su, Y.; Brown, H.M.; Huang, X.; Zhou, X.; Amonette, J.E.; Zhang, Z.C. Single-step conversion of cellulose to 5-hydroxymethylfurfural (HMF), a versatile platform chemical. Appl. Catal. A 2009, $361,117-122$.

17. Tong, X.; Ma, Y.; Li, Y. Biomass into chemicals: Conversion of sugars to furan derivatives by catalytic processes. Appl. Catal. A 2010, 385, 1-13.

18. Rackemann, D.W.; Doherty, W.O. The conversion of lignocellulosics to levulinic acid. Biofuels Bioprod. Bioref. 2011, 5, 198-214.

19. Lewkowski, J. Synthesis, chemistry and applications of 5-hydroxymethylfurfural and its derivative. ARKIVOC 2001, 2001, 17-54.

20. Chheda, J.N.; Román-Leshkov, Y.; Dumesic, J.A. Production of 5-hydroxymethylfurfural and furfural by dehydration of biomass-derived mono- and poly-saccharides. Green Chem. 2007, 9, 342-350.

21. Boisen, A.; Christensen, T.; Fu, W.; Gorban, Y.; Hansen, T.S.; Jensen, J.S.; Klitgaard, S.K.; Pedersen S.; Riisager A.; Ståhlberg T.; et al. Process integration for the conversion of glucose to 2,5-furandicarboxylic acid. Chem. Eng. Res. Des. 2009, 87, 1318-1327.

22. Deng, T.; Cui, X.; Qi, Y.; Wang, Y.; Hou, X.; Zhu, Y. Conversion of carbohydrates into 5-hydroxymethylfurfural catalyzed by $\mathrm{ZnCl}_{2}$ in water. Chem. Commun. 2012, 48, 5494-5496.

23. Van Dam, H.E.; Kieboom, A.P.G.; van Bekkum, H. The conversion of fructose and glucose in acidic media: Formation of hydroxymethylfurfural. Starch-Starke 1986, 38, 95-101.

24. Seri, K.; Inoue, Y.; Ishida, H. Catalytic activity of lanthanide (III) ions for the dehydration of hexose to 5-hydroxymethyl-2-furaldehyde in water. Bull. Chem. Soc. Jpn. 2001, 74, 1145-1150. 
25. De, S.; Dutta, S.; Saha, B. Microwave assisted conversion of carbohydrates and biopolymers to 5-hydroxymethylfurfural with aluminium chloride catalyst in water. Green Chem. 2011, 13, 2859-2868.

26. Hansen, T.S.; Mielby, J.; Riisager, A. Synergy of boric acid and added salts in the catalytic dehydration of hexoses to 5-hydroxymethylfurfural in water. Green Chem. 2011, 13, 109-114.

27. Daorattanachai, P.; Khemthong, P.; Viriya-empikul, N.; Laosiripojana, N.; Faungnawakij, K. Conversion of fructose, glucose, and cellulose to 5-hydroxymethylfurfural by alkaline earth phosphate catalysts in hot compressed water. Carbohydr. Res. 2012, 363, 58-61.

28. Choudhary, V.; Mushrif, S.H.; Ho, C.; Anderko, A.; Nikolakis, V.; Marinkovic, N.S.; Frenkel, A.I.; Sandler, S.I.; Vlachos, D.G. Insights into the interplay of lewis and brønsted acid catalysts in glucose and fructose conversion to 5-(hydroxymethyl)furfural and levulinic acid in aqueous media. J. Am. Chem. Soc. 2013, 135, 3997-4006.

29. Shen, Y.; Xu, Y.; Sun, J.; Wang, B.; Xu, F.; Sun, R. Efficient conversion of monosaccharides into 5-hydroxymethylfurfural and levulinic acid in $\mathrm{InCl}_{3}-\mathrm{H}_{2} \mathrm{O}$ medium. Catal. Commun. 2014, 50, 17-20.

30. Rasrendra, C.B.; Makertihartha, I.G.; Adisasmito, S.; Heeres, H.J. Green chemicals from D-glucose: Systematic studies on catalytic effects of inorganic salts on the chemo-selectivity and yield in aqueous solutions. Top. Catal. 2010, 53, 1241-1247.

31. Yang, Y.; Hu, C.; Abu-Omar, M.M. Conversion of carbohydrates and lignocellulosic biomass into 5-hydroxymethylfurfural using $\mathrm{AlCl}_{3} .6 \mathrm{H}_{2} \mathrm{O}$ catalyst in a biphasic solvent system. Green Chem. 2012, 14, 509-513.

32. Combs, E.; Cinlar, B.; Pagan-Torres, Y.; Dumesic, J.A.; Shanks, B.H. Influence of alkali and alkaline earth metal salts on glucose conversion to 5-hydroxymethylfurfural in an aqueous system. Catal. Commun. 2013, 30, 1-4.

33. Degirmenci, V.; Hensen, E.J.M. Development of a heterogeneous catalyst for lignocellulosic biomass conversion: Glucose dehydration by metal chlorides in a silica-supported ionic liquid layer. Environ. Prog. Sustain. Energy 2013, 33, 657-662.

34. Loerbroks, C.; van Rijn, J.; Ruby, M.R.; Tong, Q.; Schuth, F.; Thiel, W. Reactivity of metal catalyst in glucose-fructose conversion. Chem. Eur. J. 2014, 20, 12298-12309.

35. Pagán-Torres, Y.J.; Wang, T.; Gallo, J.M.R.; Shanks, B.H.; Dumesic, J.A. Production of 5-hydroxymethylfurfural from glucose using a combination of lewis and brønsted acid catalysts in water in a biphasic reactor with an alkylphenol solvent. ACS Catal. 2012, 2, 930-934.

36. Kobayashi, S.; Nagayama, S.; Busujima, T. Lewis acid catalyst stable in water. Correlation between catalyst activity in water and hydrolysis constants and exchange rate constants for substitution of inner-sphere water ligands. J. Am. Chem. Soc. 1998, 120, 8287-8288.

37. Fachri, B.A.; Abdilla, R.N.; Rasrendra, C.B.; Heeres, H.J. Experimental and modelling studies on the uncatalysed thermal conversion of inulin to 5-hydroxymethylfurfural and levulinic acid. Sustain. Chem. Process. 2015, 3, 1-11.

38. Gupta, A.K.; Kaur, N. Fructan Storing Plants-A potential source of high fructose syrups. J. Sci. Ind. Res. 1997, 56, 447-452.

39. Franck, A. Technological functionality of inulin and oligofructose. Br. J. Nut. 2002, 87, S287-S291. 
40. Wu, S.; Fan, H.; Xie, Y.; Cheng, Y.; Wang, Q.; Zhang, Z.; Han, B. Effect of $\mathrm{CO}_{2}$ on conversion of inulin to 5-hydroxymethylfurfural and propylene oxide to 1,2-propanediol in water. Green Chem. 2010, 12, 1215-1219.

41. Benvenuti, F.; Carlini, C.; Patrono, P.; Raspolli Galletti, A.M.; Sbrana, G.; Massucci, M.A.; Galli, P. Heterogeneous zirconium and titanium catalysts for the selective synthesis of 5-hydroxymethyl-2-furaldehyde from carbohydrates. Appl. Catal. A 2000, 193, 147-153.

42. Carlini, C.; Giuttari, M.; Galletti, A.M.; Sbrana, G.; Armaroli, T.; Busca, G. Selective saccharides dehydration to 5-hydroxymethyl-2-furaldehyde by heterogeneous niobium catalysts. Appl. Catal. A 1999, 183, 295-302.

43. Carlini, C.; Patrono, P.; Gallettia, A.M.R.; Sbrana, G. Heterogeneous catalysts based on vanadyl phosphate for fructose dehydration to 5-hydroxymethyl-2-furaldehyde. Appl. Catal. A 2004, 275, 111-118.

44. Despax, S.; Maurer, C.; Estrini, B.; le Bras, J.; Hoffmann, N.; Marinkovic, S.; Muzart, J. Fast and efficient DMSO-mediated dehydration of carbohydrates into 5-hydroxymethylfurfural. Catal. Commun. 2014, 51, 5-9.

45. Harvey, D.J. Matrix-assisted laser desorption/ionisation mass spectrometry of oligosaccharides and glycoconjugates. J. Chromatogr. A 1996, 720, 429-446.

46. Kazmaier, T.; Roth, S.; Zapp, J.; Harding, M.; Kuhn, R. Quantitative analysis of malto-oligosaccharides by MALDI-TOF mass spectrometry, capillary electrophoresis and anion exchange chromatography. Fresenius J. Anal. Chem. 1998, 361, 473-478.

47. Roberfroid, M. Inulin-Type of Fructans; CRC Press: Boca Raton, FL, USA, 2005.

48. Asghari, F.S.; Yoshida, H. Acid-catalyzed production of 5-hydroxymethyl furfural from D-fructose in subcritical water. Ind. Eng. Chem. Res. 2006, 45, 2163-2173.

49. Roman-Leskhov, Y.; Moliner, M.; Labinger, J.A.; Davis, M.E. Mechanism of glucose isomerization using a solid lewis acid catalyst in water. Angew. Chem. Int. Ed. 2010, 49, 8954-8957.

50. Yang, G.; Pidko, E.A.; Hensen, E.J.M. Mechanism of brønsted acid-catalyzed conversion of carbohydrates. J. Catal. 2012, 295 122-132.

51. Aida, T.M.; Tajima, K.; Watanabe, M.; Saito, Y.; Kuroda, K.; Nonaka, T.; Hattori, H.; Smith, R.L., Jr.; Arai, K. Reactions of D-fructose in water at temperatures up to $100 \mathrm{MPa}$. J. Supercrit. Fluids 2007, 42, 110-119.

52. Rasrendra, C.B.; Fachri, B.A.; Makertihartha, I.B.; Adisasmito, S.; Heeres, H.J. Catalytic conversion of dihydroxyacetone to lactic acid catalytic conversion of dihydroxyacetone to lactic acid. ChemSusChem. 2011, 4, 1-11.

53. Purushothaman, R.K.P.; van Haveren, J.; van Es, D.S.; Melián-Cabrera, I.; Meeldijk, J.D.; Heeres, H.J. An efficient one pot conversion of glycerol to lactic acid using bimetallic gold-platinum catalysts on a nanocrystalline $\mathrm{CeO}_{2}$ support. Appl. Catal. B 2014, 147, 92-100.

54. Van Zandvoort, I.; Wang, Y.; Rasrendra, C.B.; van Eck, E.R.H.; Bruijnincx, P.C.A.; Heeres, H.J.; Weckhuysen, B.M. Formation, molecular structure, and morphology of humins in biomass conversion: Influence of feedstock and processing conditions. ChemSusChem. 2013, 6, 1745-1758. 
55. Fachri, B.A.; Abdilla, R.M.; Bovenkamp, H.H.; Rasrendra, C.B.; Heeres, H.J. Experimental and kinetic modeling studies on the sulfuric acid-catalysed conversion of D-fructose to 5-hydroxymethylfurfural and levulinic acid in water. ACS Sustainable Chem. Eng. 2015, 3, 3024-3034.

(C) 2015 by the authors; licensee MDPI, Basel, Switzerland. This article is an open access article distributed under the terms and conditions of the Creative Commons Attribution license (http://creativecommons.org/licenses/by/4.0/). 